\title{
The Limits of Accounting-Based Accountability in Education (and Far Beyond): Why More Accounting Will Rarely Solve Accountability Problems
}

\section{Dan Honig and Lant Pritchett}

\begin{abstract}
Accountability is rightly at the center of the conversation regarding how to improve governance systems, particularly health and education systems. But efforts to address accountability deficits often focus primarily on improving what can be counted and verified — what we term "accountingbased accountability." We argue that introducing greater accounting-based accountability will only very rarely be the appropriate solution for addressing accountability problems. We illustrate this by exploring the role of Accountability ICT in (not) improving education system performance. Strengthening "real" accountability is not the same as improving data systems for observation and verification, and often attempts at the latter undermine the former. The development discourse's frequent semantic misunderstanding of the term "accountability" has pernicious effects on system reform efforts and ultimately global welfare.
\end{abstract}




\title{
The Limits of Accounting-Based Accountability in Education (and Far Beyond): Why More Accounting Will Rarely Solve Accountability Problems
}

\author{
Dan Honig \\ Johns Hopkins University School of Advanced International Studies \\ Lant Pritchett \\ Blavatnik School of Government, University of Oxford \\ https://lantpritchett.org/
}

Center for Global Development 2055 L Street NW Washington, DC 20036

202.416 .4000

(f) 202.416 .4050

www.cgdev.org
Many thanks to Paul Carlile, Luis Crouch, Alice Evans, Bob Gibbons, Michelle Kaffenberger, Charles Kenny, Brian Levy, Mark Moore, Paul Skidmore, and Chris Wilson for their wise comments on earlier drafts, which does not make them accountable for the final results.

Dan Honig and Lant Pritchett, 2019. “The Limits of Accounting-Based Accountability in Education (and Far Beyond): Why More Accounting Will Rarely Solve Accountability Problems.” CGD Working Paper 510. Washington, DC: Center for Global Development. https://www.cgdev.org/publication/limits-accounting-based-accountability-educationand-far-beyond-why-more-accounting-will

The Center for Global Development works to reduce global poverty and improve lives through innovative economic research that drives better policy and practice by the world's top decision makers. Use and dissemination of this Working Paper is encouraged; however, reproduced copies may not be used for commercial purposes. Further usage is permitted under the terms of the Creative Commons License.

The views expressed in CGD Working Papers are those of the authors and should not be attributed to the board of directors, funders of the Center for Global Development, or the authors' respective organizations. 


\section{Contents}

Section I. Account-based Accountability and Accounting-Based Accountability .................. 5

Section II. Why Education Accountability Solutions Need More Account and less

Accounting, and thus why Accounting-based Accountability ICT Is a Bad Idea ................12

Section III. Accounting-based Accountability and ICT, as Seen through Historic Evidence

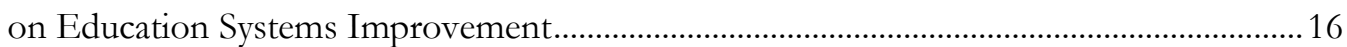

Section IV. Technology, Governance, and Productive Limits Far Beyond the Realm of

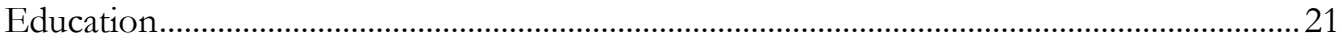

Section V. Accounting-Based Accountability as Input not Answer .......................................22

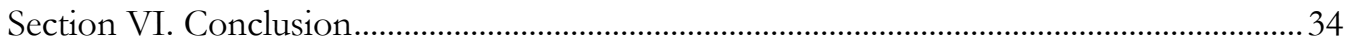

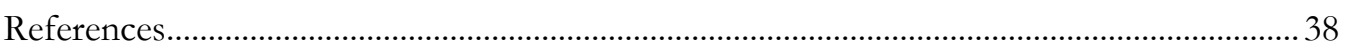

Appendix I: "Moore's Law Amenable" and "Moore's Law Resistant" Activities................ 44

Appendix II: A Modestly More Technical Approach to Evidence Suggesting That Accountability ICT in Education, and Governance More Broadly, Is Not Transformative 
Yet the gross national product does not allow for the bealth of our children, the quality of their education, or the joy of their play. It does not include the beauty of our poetry or the strength of our marriages, the intelligence of our public debate or the integrity of our public officials. It measures neither our wit nor our courage, neither our wisdom nor our learning, neither our compassion nor our devotion to our country, it measures everything in short, except that which makes life worthwbile. And it can tell us everything about America except why we are proud that we are Americans. -Robert F. Kennedy (1968)

Woody Allen is credited with saying $80 \%$ of success is just showing up. ${ }^{1}$ Surely this applies not least to educators - and a teacher's absence affects not just their success, but those of the young minds in their care. Teacher absenteeism is a massive, well-documented, longstanding problem in the developing world (see Figure 1). ${ }^{2}$ Figure 1's data come from an article in which teacher absenteeism is framed as the product of "systemic governance, accountability, and management issues." (Bold et. al. 2017, page 3) We agree; and inasmuch as this is a paper about strategies to address accountability failures with a particular focus on education systems in the developing world, attempts to address teacher absenteeism seems a good place to begin.

\footnotetext{
${ }^{1}$ Though it's not clear he ever actually said it publicly. See here: https://quoteinvestigator.com/2013/06/10/showing-up/, so maybe, ironically, he didn't even show up on this one.

${ }^{2}$ Courtesy of Our World In Data, used under Creative Commons license, using data from Bold et. al. 2017 from the Service Delivery Indicator data collected by the World Bank. Chronic teacher absence in India surfaced in the PROBE report of 1999 (based on data from the mid-1990s in five states), followed up by studies for the World Development 2004 in 2003 (Chaudhury et al 2006) and then again in 2010 (Muralidharan et al 2017), who found the national average only down to 23.6 percent in 2010 from 25 percent in 2003.
} 
Figure 1. Percentage of teachers absent from school

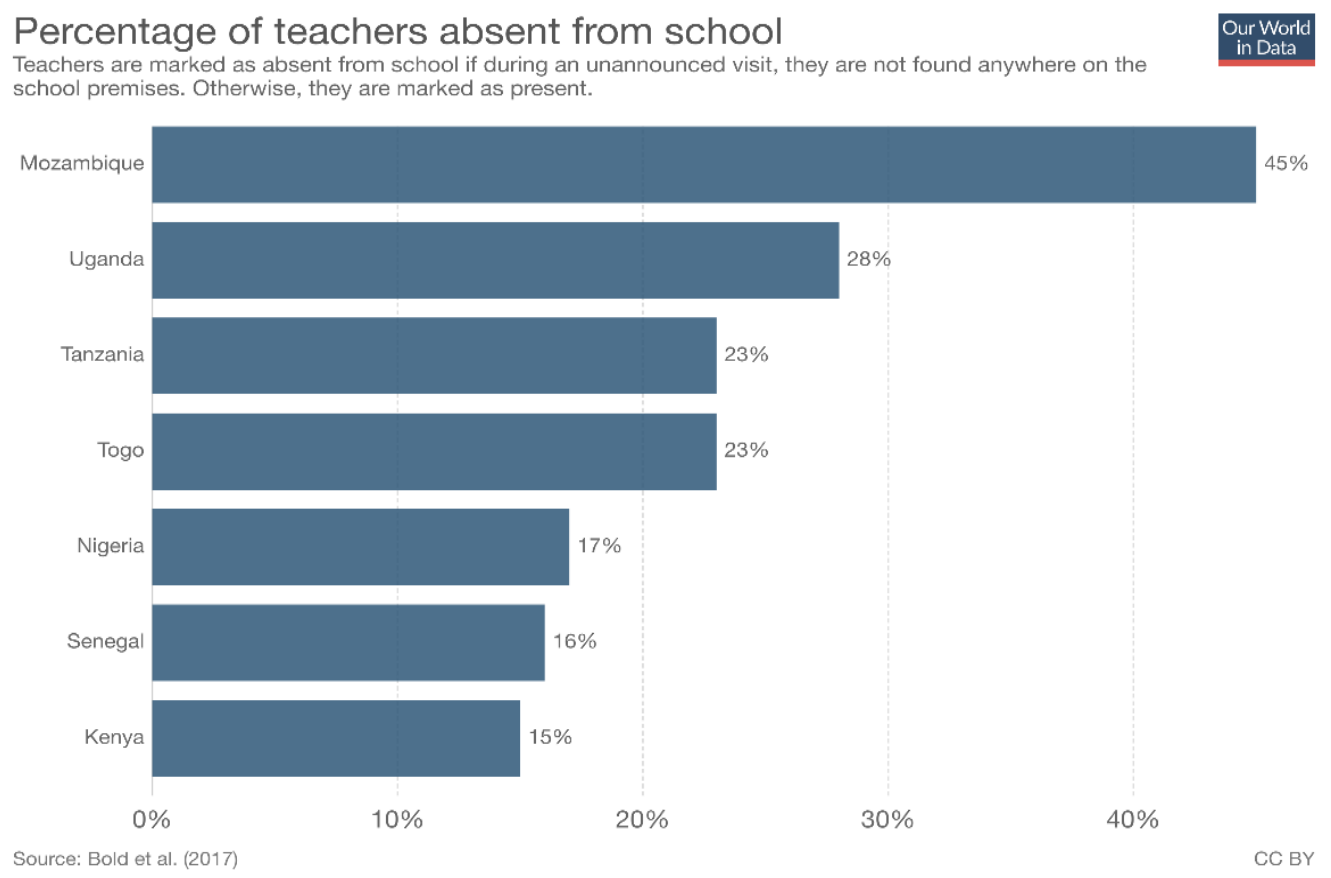

So how to address the governance, accountability, and management issues that underlie teacher absenteeism? One relatively straightforward, seemingly attractive solution is to use technology to track when teachers show up, and reward them when they do. A randomized control trial (RCT) tested this strategy in Indian informal schools run by the NGO Seva Mandir, evaluating whether putting digital cameras with time-date stamps in schools to monitor attendance and compensating teachers who more frequently attended improved teacher attendance and student performance. (Duflo et. al. 2012) The results? Absenteeism was approximately halved, falling from $42 \%$ to $21 \%$. And students did indeed perform better-with test scores .17 of a standard deviation better in the treatment than in control schools, which on a normal distribution would be approximately the gap between the $50^{\text {th }}$ and the $57^{\text {th }}$ percentile.

The Government of Delhi is proposing taking what worked in NGO schools and scaling up, installing 140,000 cameras in public school classrooms. While objections to this plan have been raised by teachers and others, in late 2018 the Government secured High Court blessing for its plan. (Indian Express 2018) But it is by no means obvious that Delhi's public schools will see similar performance improvements in the public schools as were observed in the original trial.

There is evidence that similar solutions to fix accountability may not work when actually implemented in or by Government organizations. The same NGO as in the Indian school cameras intervention-Seva Mandir-also worked with public clinics in the Indian state of Rajasthan to improve monitoring to address health worker (the sub-centre based auxiliary nurse midwives) absenteeism. An RCT of that intervention was carried out by some of the same very prominent economists. The result? The paper's title tells the story. "Putting a 
Band-Aid on a Corpse" documents that, while the attendance monitoring and financial incentives initially led nurses to attend more frequently the controls were quite quickly and fully thwarted, resulting in no long term increase in nurse attendance-in the "treatment" areas attendance was lower after the project. (Banerjee et al., 2008)

Seemingly 'successful' implementations may also have negative impacts. Another attempt to improve health worker attendance in India subjected to at RCT resulted in an even more depressing title_-"Deal with the Devil." (Dhaliwal \& Hanna, 2014) In this case, a technology solution to monitor attendance did actually improve attendance of health care staff (though not of doctors). So why the downbeat title? Because these authors carefully tracked, and clearly describe, substantial negative spillovers of the intervention. Patients were shunted to, or chose to go to, private clinics, reducing the number of patients seen in the monitored facilities; staff at monitored health centers were more dissatisfied with their jobs; it was harder for monitored facilities to fill vacancies. Despite these findings, the authors express hope for interventions that attempt to solve accountability problems via observation and control. As they put it, "there are potentially very large returns to implementing a technology to better ensure that government workers adhere to formal rules" (p. 30); "reform is possible, especially with technological solutions that can bypass the poor incentives, overlapping institutional structures and individual discretion failures that make it easier for bureaucrats to ignore the existing rules and extract rents." (p. 29) For these authors, apparently the "devil" is getting the particulars of the intervention right—-the devil is in the details.

We believe the devil is not in the details of the intervention, but rather in the theory of change upon which it is premised-in the belief that technology driven interventions of this type are a promising route to systems improvement. We agree that teacher absenteeism is a massive problem. We agree it is fundamentally about a failure of accountability. But we disagree that attempts to address this accountability failure that focus on gathering the easily verifiable information amenable to digital transmission, writing tighter contracts on "thin" inputs, and more generally on strengthening top-down managerial control-what we call accounting-based accountability — are the best, or even a very good, or even a possible, way to address absenteeism for the great majority of public sector workers in the developing world, including (but not limited to) teachers and front line health workers.

This paper is primarily concerned with accountablility and systems improvement, and specifically in arguing that even well-implemented accountability interventions based around strengthening top-down control may not in fact be good strategies for improving system performance. One of the reasons for opening this paper with teacher absenteeism-a clear problem for which we have rigorous evidence that an accounting-based accountability solution shows local treatment effects of greater teacher attendance and improved student learning - is to set ourselves a somewhat high bar. We hope to persuade you by the end of this paper that despite the documented teacher attendance and student learning gains, policymakers and education reform efforts would put their time and energy to better use by focusing not on cameras in classrooms on accounting-based accountability solutions more generally, but on pursuing strengthened accountability in ways that is account-based. This is not only because it may prove difficult to implement cameras or other accounting-based 
accountability solutions that have shown promising results in small-scale trials at scale, as either 'high politics' precludes adoption or 'low politics' thwarts fidelity of implementation in practice. It is because even if these challenges are overcome, we believe monitoring teacher attendance via cameras will prove, in many settings, a very bad idea.

Our view of the dim prospects of these types of interventions, and top-down attempts to improve accountability through observation, verification, and counting more generally, follows from our recent work, which we think speaks to the question of attempts to strengthen accounting-based accountability in education. One of us has two recent books, one about building state capability in developing countries (Andrews, Pritchett and Woolcock, 2017) and one about improving learning in basic education systems in developing countries (Pritchett, 2013). The other has a recent book on the limits and perils of relying on accounting-based accountability in managing development efforts (Honig, 2018). Weaving these threads together, we want to explain why we think that technological tools that strengthen accounting-based accountability will play a small, limited role in improving accountability and public-sector governance.

To make our broader points about accountability and systems improvement we are going to focus on education systems and ICT accountability 'solutions'. We see education systems as constrained primarily by governance and accountability failings rather than by the availability (or not) of necessary technical inputs (Pritchett 2015). Governance is at the heart of many development challenges that are often framed as technical domains. One such domain is improving education in developing countries. The attendance monitoring cameras are, in our view, one of a suite of proposed solutions to accountability concerns we term "Accountability ICT"- -attempts at addressing accountability failures via technology-enabled greater observation and control. We believe ICT can do many valuable things, including in the education sector. It can be a useful input into student learning and teachers' teaching practices, including through adaptive lessons and distance learning. But ICT is very unlikely to solve governance problems, or improve accountability, which we agree is the most fundamental constraint to progress. This is because the fundamental issues in improving governance, and in particular education governance, are about creating organizations with strong account-based accountability and Accountability ICT helps primarily (if not only) with accounting-based accountability.

We believe that the "very large returns to implementing a technology to better ensure that government workers adhere to formal rules" which Dhaliwal \& Hanna (2014, p. 30) envisage will be possible only where (a) the key activity in the productive value chain is currently significantly constrained by accounting-based accountability of the type accounting-based accountability, including Accountability ICT, can easily improve and (b) the relevant organizations' account-based accountability is already strong enough. The first is typically not true of education and the second is rarely true in developing country government organizations.

Pursuit of accounting-based accountability solutions like the camera-attendance solution can easily make things worse, not better, by focusing on a top-down approach to accountingbased accountability for "thin inputs" (Pritchett 2014) or "process compliance" (Levy et al 2018) that (i) are not currently key or essential constraints to value added, (ii) distract 
attention away from building organizations with strong account based accountability, and (iii) may undermine account based accountability both externally (to "clients") and horizontally (to "peers"). We believe e.g. cameras in classrooms succeed on (i)—addressing a key constraint—but fail on (ii) and (iii).

We believe strong systems of accountability for overall performance-including learning outcomes - is essential to creating high quality education opportunities for all children around the world. We worry that ICT-based efforts attempting to create accountability strictly through accounting-based accountability is, at best, a distraction from that goal. We believe these types of solutions are receiving far too much emphasis in current discussions.

\section{Section I. Account-based Accountability and Accounting- Based Accountability}

Organizations that induce large-scale cooperation by empowering individuals to act to further the purposes of the organization - whether it be religious, social, military, political, or purely economic - create an accountability process that relies on agents at each level, from top to bottom, providing an account. These accounts flow "up" to the top, with each level of the organization generating an account to their superiors. There are also types of accountability that do not flow from top to bottom. There is "horizontal" accountability, which can function within a single organization (e.g. amongst peers) or across organizations (e.g. within professional networks). Surgeons are accountable to the hospital or clinic in which they operate, but they are also strongly conditioned as surgeons to feel accountable to the idea of the association or profession of a surgeon as an important normative construct. Personally, as academics we care about our reputations as development scholars. This is a strongly felt horizontal accountability, even if only to a loosely defined, and quite narrow, community of "experts" on economics and development. This is an account based accountability that has no formal structures or processes.

There can also be accountability that flows from the "bottom" up; the market is one such source of accountability. When people provide services to others, there is a direct accountability to the people served. Even if your dentist is a sole proprietor, not part of any large organization, she is accountable to her patients, both as a normative obligation but also reinforced by the fact that she relies on (repeat) patients for her livelihood.

Accountability is critically important. But for all of the ink spilled discussing accountability, there are relatively few explorations of what in fact it means to be "accountable." The essence of accountability is — or on our view ought, both normatively and positively, be-an "account," a narrative that a person tells of what they did and why they did it, and why what they did was right. In this belief, we follow the dictionary; Merriam-Webster defines 
"accountability" as "the quality or state of being accountable," and "accountable" as "subject to giving an account."3

What, then, is it to give an account? It's "to furnish a justifying analysis or explanation." 4 That is, an account given by a public employee explains why what they did was the desirable and honorable action to be done in the circumstances to accomplish the agreed-upon purpose for which resources were made available. One part of nearly all accounts includes some degree of what we call "accounting." By "accounting" we mean numbers, usually "hard" (cardinal) numbers, about quantities widely regarded as "objective." Accounting can cover inputs, activities, outputs, or outcomes, and is part of the "justifying analysis" referred to in the definition. But the accounting is only a part of what can constitute justifying analysis, rather than being itself synonymous with the "account." 5

Tasks, and by extension professional roles and whole organizations, vary in the degree to which accounting-based accountability is appropriate. In some cases, accounting-based accountability is reasonably complete. For example, if a process server has a clear record of delivering a subpoena to a target, this is a verifiable accounting that seems to nearly completely account for the process server's completion of their task. That is less the case for the judge presiding over the trial where the subpoena target testifies. Judicial accountability is not confined to verifiable features like showing up at the courthouse on time, or the number of days of each trial. The judge's job involves substantial exercise of judgment, and as such we as a society ask judges not just to issue a verdict but to write a lengthy opinion supporting their verdict—a judicial opinion. Opinions are accounts; ones that incorporate verifiable facts of the case and citable precedent, but that also have a strong component of reasoning and interpretation. Opinions are publicly issued, so that others can interrogate the accounts contained. These others include fellow judges (horizontal accountability), the public (bottom-up accountability), and judicial review boards (top-down accountability). When-as in the case of judges_-accounting plays little role in making of an account, we term this account-based, rather than accounting-based, accountability. ${ }^{6}$

What we mean by the distinction between "account" and "accounting" has, we believe, a number of echoes from a variety of literatures, which we briefly survey in Table 1 . We are hardly the first to make a distinction like this. What emerges from Table 1 is the

\footnotetext{
${ }^{3}$ Merriam-Webster. "Accountable" and "Accountability." https://www.merriamwebster.com/dictionary/accountable; http s://www.merriam-webster.com/dictionary/accountability\#h1.

${ }^{4}$ Merriam-Webster, “Account.” https://www.merriam-webster.com/dictionary/account. The quoted definition is not the only one offered, but is the one that most clearly fits the conventional use of "accountability."

5 This in many ways echoes arguably the most prominent definitions of accountability in international relations, as when "some actors have the right to hold other actors to a set of standards, to judge whether they have fulfilled their responsibilities in light of these standards" (Grant \& Keohane 2005, 29). Accounting-based accountability can and does sometimes form part of evaluating whether standards have been met, but is not the only possible form of accountability.

${ }^{6}$ That is, by account-based accountability we mean "accountability where accounting-based accountability plays little role."
} 
interrelationship between discretion, motivation, and accountability in affecting performance and achieving organizational goals. Accounting-based accountability has implications for how much discretion or autonomy agents have and their motivation. While our primary focus on this paper is the flaws of accounting-based approaches to strengthening accountability, we believe these strategies are flawed precisely because of the broader implications of accounting-based accountability approaches. 
Table 1. The many echoes of accounting-based vs. account-based accountability

\begin{tabular}{|c|c|c|}
\hline $\begin{array}{l}\text { Accounting-Based } \\
\text { Accountability }\end{array}$ & $\begin{array}{l}\text { Account-Based } \\
\text { Accountability }\end{array}$ & Disciplinces/Source(s) \\
\hline Thin Accountability & $\begin{array}{l}\text { Thick } \\
\text { Accountability }\end{array}$ & $\begin{array}{l}\text { Public Management/ Anthropology/Development Studies: Used with allusion to Geertz' (1973) "thick description", though } \\
\text { also has echoes of Fox' (2007) distinction of soft vs. hard accountability. Dubnick \& O'Kelly (2005) has some work } \\
\text { directly on thick vs. thin accountability. The core notion is that thin, superficial, easily observable "thin" data is } \\
\text { incomplete as a basis for accountability. }\end{array}$ \\
\hline $\begin{array}{l}\text { Sanctions-based } \\
\text { Accountability }\end{array}$ & $\begin{array}{l}\text { Deliberative } \\
\text { Accountability } \\
\text { (selection-based } \\
\text { Accountability) }\end{array}$ & $\begin{array}{l}\text { Political Pbilosophy: Mansbridge's work on accountability, which stresses the oft-desirable deliberative features of } \\
\text { accountability (e.g. Mansbridge, 2003) and the failure of top-down monitoring linked to sanctions as a control } \\
\text { technology and thus the importance of "giving an account" (Mansbridge, 2014). We combine these threads and apply } \\
\text { them to bureaucracies rather than (as in Mansbridge) legislators. }\end{array}$ \\
\hline $\begin{array}{l}\text { Formal Authority's } \\
\text { Top-Down Control }\end{array}$ & $\begin{array}{l}\text { Real Authority's } \\
\text { Agent Initiative }\end{array}$ & $\begin{array}{l}\text { Economics (Contract Theory): Aghion \& Tirole (1997) note the fundamental tension between principal control and agent } \\
\text { initiative. Where agent initiative which cannot be monitored or contracted on is an important part of the production } \\
\text { process, sometimes top-down control will preclude behavior the principal desires. }\end{array}$ \\
\hline Hard Information & Soft Information & $\begin{array}{l}\text { Economics (Finance): Stein (2002), in a very widely cited paper, notes that the more important soft information that } \\
\text { cannot be hardened (codified/verified/transmitted up a hierarchy/used for accounting-based accountability), the less } \\
\text { effective tight top-down hierarchy. }\end{array}$ \\
\hline Complete Contracting & $\begin{array}{l}\text { Incomplete (and } \\
\text { particularly } \\
\text { Relational) } \\
\text { Contracting }\end{array}$ & $\begin{array}{l}\text { Economics (Contract Theory): The relational contracting literature arguably launched by Baker, Gibbons, \& Murphy (1994, } \\
1999,2002 \text { ) focuses on mutual understandings about the appropriate use of discretion, recognizing that contracts } \\
\text { cannot be complete (foreseeing all possible outcomes), nor is tight monitoring always the right strategy. }\end{array}$ \\
\hline Theory X & Theory Y & $\begin{array}{l}\text { Organizational Behavior/Management: Mcgregor's (1960) distinction between two management-motivation equilibria: One } \\
\text { with workers with little motivation who wish to shirk and tight management control and use of rewards and } \\
\text { punishment (Theory X) and motivated employees who are given decision rights and empowered by their managers } \\
\text { (Theory Y). }\end{array}$ \\
\hline $\begin{array}{l}\text { Navigation from the } \\
\text { Top }\end{array}$ & $\begin{array}{l}\text { Navigation by } \\
\text { Judgment }\end{array}$ & $\begin{array}{l}\text { Political Science/ Organizational Behavior/Public Management: Honig (2018) draws a distinction between tasks where top- } \\
\text { down control and thus accountability "up" the headquarters and political authorizers is a good management strategy, } \\
\text { and those where environmental uncertainty and/or the difficulty of verifying good outcomes means aid agencies } \\
\text { would be best led by the judgment of development practitioners at the coal face of implementation. }\end{array}$ \\
\hline
\end{tabular}




\begin{tabular}{|c|c|c|}
\hline $\begin{array}{l}\text { Management by } \\
\text { Observation, Control, } \\
\text { Verification: Scientific } \\
\text { Management/Audit } \\
\text { Society/Tyranny of } \\
\text { Metrics/Obsessive } \\
\text { Measurement Disorder }\end{array}$ & $\begin{array}{l}\text { Trust-Based } \\
\text { Management }\end{array}$ & $\begin{array}{l}\text { Management: Taylor's (1917) Scientific management focused on achieving better results through observation and top- } \\
\text { down control. By contrast, trust-based management (e.g. as currently being implemented in Sweden; Tillit 2018) } \\
\text { focuses on establishing trust and dialogue between front-line workers and clients. The tension between top-down } \\
\text { control and trust is also apparent in Power's (1997) Audit Society, in its focus on process compliance/verification as in } \\
\text { tension with trust. Porter's (1995) Trust in Numbers and Muller's (2018) Tyranny of Metrics provide nice historical } \\
\text { and society-wide complements on the potential limitations of Accounting-based Accountability, and Natsios' (2010) } \\
\text { Obsessive Measurement Disorder provides a development-focused complement in examining USAID. }\end{array}$ \\
\hline High Modernism & Metis & $\begin{array}{l}\text { Sociology/Political Science/Public Management: James Scott's (2008) distinction between attempts to "improve the human } \\
\text { condition" that proceed by top-down planning from above, in contrast to those the focus on the difficult-to-codify } \\
\text { local knowledge and wisdom of those on the ground. }\end{array}$ \\
\hline \multicolumn{2}{|c|}{ Other } & $\begin{array}{l}\text { One might think a table this long is exhaustive, but in many ways it is only the beginning. Anthropology offers The } \\
\text { Seductions of Quantification (Merry 2016) and accounts of accounting-based thin accountability like Hull's (2012) } \\
\text { masterful Government of Paper on urban Pakstan. Sociology has a whole literature on commensurability, on what is lost } \\
\text { when comparisons are made via thin, accounting-based metrics. (e.g. Espeland and Sauder, 2016) From political } \\
\text { science and planning, Tendler (1997) provides vivid accounts from Brazil of the failure of accounting-based } \\
\text { accountability and marked successes in cultivating 'Theory Y' behaviors in part via account-based accountability (most } \\
\text { notably amongst front line community health workers very similar to those described in "Deal with the Devil" above; } \\
\text { see also Tendler \& Freedheim, 1994). From the design world, human-centered design (which is arguably account- } \\
\text { based) as contrasted with blueprint approaches has echoes of the account- vs. accounting-based distinction, as does } \\
\text { (from management/organizational behavior) Bernstein's transparency paradox; that is, the insight that "Broad } \\
\text { visibility, intended to increase transparency, can breed hiding behavior and myths of learning and control." (Bernstein } \\
\text { 2012, p. 209) }\end{array}$ \\
\hline
\end{tabular}


By all this we do not mean to say that heavily accounting-based accountability is in all situations a bad management strategy. There is no universal truth to the question of to what extent accountability, and giving an account, ought to be composed of accounting. It depends on the nature of the task, the agents, and the organization. Particularly important in the relationship between accountability and task is the extent to which the task undertaken can be verified - to which performance can be observed, and thus a complete contract can be written to induce the behavior management desires. For lower-level functionaries in organizations with "top down" management that are doing what one of us in Building State Capability (Andrews, Pritchett, Woolcock, 2017) calls "logistics," performance can be judged strictly by the numbers. In a post office compliance with existing processes and procedures and accounting based on "thin inputs" — where "thin" here is the opposite of "thick" in the sense of "thick description" of Clifford Geertz (1973) — is all that is asked. Accounting completely satisfies what it needs for full accountability. The other of us (Honig, 2018) finds that relying on accounting-based accountability is sometimes the best way of managing development projects where they are primarily logistical—e.g. building a road, or delivering anti-retroviral drugs - consistent with this logic. The process server ought to be managed with a very heavily accounting-based accountability scheme, as the task is primarily logisticaldelivering a notice.

In contrast, in other activities it is obvious that the thin measurement of accounting fails to capture in important and essential ways what agents are expected to do. Hence, accounting plays a lesser role in what it means to make an account. Indeed, a large literature in economics makes clear that where accounting is incomplete, reliance on accounting for control purposes is often misguided. ${ }^{7}$ As a result, many high-performing organizations treat accounting as an input - a component of the account-rather than the whole of an account. For example, after any engagement, an army officer will have to provide an account of their (and their unit's) actions. In this certainly there is accounting: men and material lost, objectives gained or failed. But the account is not exhausted by the simple thin accounting of inputs or outputs. Like judges, army officers appropriately labor under an accountability regime wherein accounting forms a part, but by no means the whole, of what it means to

\footnotetext{
${ }^{7}$ We are thinking primarily here of Holmstrom Milgrom (1991) multitasking and the variety of papers that build on it. As Holmstrom put it in his Nobel Laureate address in 2016, "One of the main lessons from working on incentive problems for 25 years is, that within firms, high-powered financial incentives can be very dysfunctional and attempts to bring the market inside the firm are generally misguided." (Holmstom 2016, 415). Accountingbased accountability creates performance incentives (whether there are explicit financial rewards or otherwise) towards what can go into accounting systems. This means agents will meet targets but do less of anything unaccounted for, and has led a number of scholars to focus on the sometimes deleterious role of monitoring and 'high-powered' incentives (Bowles \& Polana-Reyes 2012, Gneezy et al 2011), particularly in the public sector (Dewatripont et al. 1999, Dixit 2002). Similar points are also made in many other disciplines, of course; e.g. Kerr (1975) makes the point in a general management context in his "Folly of Hoping for A, While Paying for B". A key feature of the public sector is that, unlike the private sector, the size/bounds of the firm (and thus solutions to the 'make' vs. 'buy' problem) cannot be fully endogenous to appropriate accountability structures and this can lead to "organizational design mismatch" between task and organizational form in the public sector (Pritchett 2014). Public sector firms thus operate at larger scale (and thus are attracted to thin accounting-based accountability, which scales more easily) even when it is perhaps inappropriate to the task. This is an area in which we plan further research.
} 
account for performance. We believe the same is true of teachers and education systemsthat these are tasks better suited to account based accountability, supported rather than dominated by accounting-based accountability.

Another part of the purpose of Table 1 is to suggest that we don't think we've invented something new here, so much as taken a distinction implicit in many, many other theories and - we hope-pointed out an important common related thread and/or implication for the discourse on accountability. A fair related question is: Dan, Lant, if all these other terms exist, why bother creating your own? Why are you prompting me to think about new and linguistically cumbersome terms like "account-based" and "accounting-based" accountability?

Our answer is that we think the term "accountability" has been hijacked by those who read it exclusively as "accounting-based accountability", and act accordingly. And once "accountability" is defined in this narrow way the tech and ICT crowd can imagine a central role for increased and improved transmission of 0 s and 1s to be the solution to deep social problems.

We don't want to give up on accountability, which we believe is appropriately central to the discourse on performance and developing world systems improvement. We just want to prompt a rethinking of what in fact accountability is, and thus the manner in which accountability failures ought be addressed.

We believe the contemporary connotation of "accountability" far too often is to imagine that the term focuses exclusively on "accounting-based accountability", and that this is a pretty big problem in how we talk about accountability in the public sector. While this problem may by definition be a semantic concern — one related to meaning in language — it is a semantic concern with very tangible real-world implications. We have both been in roomsand we suspect this is true of many readers as well-where someone is describing a management practice that has, or the room agrees is likely to, lead to improved performance with no increase in costs. "But", some wise man says knowingly, ${ }^{8}$ "what about accountability?" Everyone around the table nods-because, of course, who could be against accountability? The conversation then, mistakenly, turns to exclusively accounting-based accountability—what can be easily counted, measured, converted to 0 s and $1 \mathrm{~s}$, reported, transmitted by ICT.

This makes no sense. If a proposed reform leads to better performance at the same or lower cost, it is in fact increasing "value for money" or "taxpayer value" or "shareholder value". It should please anyone concerned about "holding the public service accountable", not send us collectively running towards the best accounting-based accountability solution we can find.

\footnotetext{
8 We do not in any way mean to imply women could not make this point, but in our experience this is a statement almost always uttered by a self-assured man in a slightly knowing tone. We do not mean this as a compliment to our gender - much the opposite.
} 
Treating accountability as if it need always be accounting-based-by which we mean, following Table 1, something like: a thin, sanctions-based accountability where the only things that matter are hard information and formal reporting of quantifiable numbers, and we can write complete contracts with bureaucrats that imply we can ignore motivation because we're in a Theory X world and should Navigate from the Top using, possibly, scientific management in a high modernist way-is a bad idea. It is a bad idea because it assumes that motivation and discretion and soft information and all the rest of the items that are more strongly associated with account-based accountability are never more important than those items more associated with accounting-based accountability. Billy Bragg (2018) argues in a recent song that "Not everything that counts can be counted/Not everything that can be counted counts." If we limit our solutions to governance, accountability, and management problems to only what can be "counted", we will at least sometimes-and we believe quite often—end up getting less of what "counts" as a result.

\section{Section II. Why Education Accountability Solutions Need More Account and less Accounting, and thus why Accounting-based Accountability ICT Is a Bad Idea}

Accounting-based accountability solutions should be expected to have substantial impacts in improving the efficiency and efficacy of governments in carrying out activities that are, by their analytical nature, logistical. There may well be some public-sector bureaus where accounting-based accountability is likely to improve performance (e.g. post office delivery or vaccine delivery). But we do not think schools and education systems are likely candidates. In essence, this is because principals and teachers and the education enterprise as a whole is much more "judge" than it is "process server."

The heart of a successful education system is the right blend of organizational, horizontal, and direct external accountability. For the backbone of an education system, teachers, accountability needs to be account-based accountability, as the key elements of what teachers do is not at all amenable to the accounting-based accountability which Accountability ICT can strengthen. An education system that is centered around learning needs to deploy teachers who have adequate resources and capacities, and who act with sincere concern for the learning progress of each child (where "learning" includes all aspects and purposes of education, not just those easily amenable to measurement like cognitive skills). If you think of what you want for your own child (if you have one), it is hard to reduce what you want from your child's teacher to a list of "hard" characteristics (e.g. has a master's degree) or "thin" behaviors (e.g. is in attendance). While those might be part of it, the accounting cannot be a complete list of what you want your child's teacher to be. "Acting with

\footnotetext{
9 So while we embrace "value for money", provided that "value" is more than merely that which accountingbased accountability can verify, we reject phrases with which it is often closely associated - e.g. ensuring "every cent" (US) or "every penny in the pound" (UK) or "every crown" (Sweden) is accounted for. We agree wholeheartedly with Kenny (2017)--the point is "Results, not Receipts."
} 
concern," much less "acting with sincere concern," for each child is not amenable to improvement with accounting-based accountability.

By Accountability ICT in education, we mean the use of information and communication technology as a tool of observation and control of the human beings delivering educational inputs. Data dashboards for managers are an example of Accountability ICT. So are abuse reporting systems wherein, for example, smartphone users text in incident reports about abusive teachers. ${ }^{10}$ A computer tablet in a teacher's hands which records when they turn the page and the pacing of their lesson is Accountability ICT; the same tablet as a resource for the teacher to use in finding model lessons or activities, or in the hands of a student engaging in a self-directed lesson, is not.

We focus on Accountability ICT not because we believe ICT plays no useful role in the world or in education systems, or because we think that all accounting-based accountability uses Accountability ICT. Rather, we center this and the next sections on Accountability ICT in education because this focus allows us to be more concrete about efforts to address systemic governance problems via thin, accounting-based accountability solutions. And, frankly, we see lots of examples of in our view misguided attempts to use Accountability ICT to strengthen accounting-based accountability in education. Accountability ICT is far from the only use of ICT in education, and ICT is far from the only strategy employed by donors and school operators to strengthen accounting-based accountability. But Accountability ICT receives substantial money and substantial investments of scarce time and attention from reformers attempting to improve education systems.

While we are confident that practitioners and scholars working on education systems in the developing and developed worlds can think of myriad attempts to address accountability failures via accounting-based Accountability ICT, those more distant from the field may not be aware of the frequency and fervor with which Accountability ICT is championed. The World Bank, among many others, supports Education Management Information Systems (EMIS) activities, e.g. systems "to collect, analyze, and distribute data on education systems;" efforts to "strengthen government capacity to analyze data;" and "development of or improvements to systems to manage data on human resources."11 Between 1998 and 2017, the World Bank funded projects with EMIS components in 109 countries. That's not a typo: the majority of the world's countries have received EMIS support. Indeed, this country count in some sense understates the scope of the World Bank's EMIS efforts, as some countries have received multiple projects, and there are EMIS regional projects as well. The World Bank lists 361 unique projects with an EMIS component. So devoted to accounting-based accountability are EMIS' enthusiasts that the World Bank has an "EMIS Project Dashboard" for aggregating and visualizing EMIS projects, deploying Accountability ICT as a tool for

\footnotetext{
${ }^{10}$ So we consider both "police patrols" and "fire alarms" (in the sense of McCubbins and Schwartz, 1984) to be Accountability ICT.

11 World Bank, "Education Management Information Systems." Drawn from EMIS Activity Definitions, downloaded at http://datatopics.worldbank.org/education/ files/EducationProjects/EMISActivityDefinitions.xlsx
} 
holding the EMIS' Accountability ICT efforts accountable. ${ }^{12}$ While it's difficult to calculate the precise dollar value committed to the World Bank for EMIS, if 3 million USD were spent on EMIS in each project-likely a very low estimate- that would be well over a billion USD spent by the World Bank on EMIS. ${ }^{13}$ And the World Bank funding is but the tip of the global iceberg. One 2017 estimate of the size of the Global Student Information System market put its 2017 value at well over 3 billion dollars annually, expected to rise to approximately 7 billion USD annually by $2022 .{ }^{14}$

The World Bank is by no means alone in its embrace of Accountability ICT. The US Government Strategy on Basic Education covering fiscal years 2019-2023 establishes an Interagency Working Group on technology and innovation. This is in part because "harnessing technology and innovation" is purported to "improve transparency and accountability." 15 Faith in Accountability ICT persists even in the face of acknowledgment that early efforts have had mixed results at best. As a UNESCO staff member put it in a piece hosted by the Global Partnership for Education, there are numerous examples of the "ICT-project-goes nowhere scenario."16 The answer? UNESCO support for national-level "ICT in education master plans," which include a focus on "ICT for better monitoring and evaluation," presumably at least in part via Accountability ICT. ${ }^{17}$

Nor is Accountability ICT constrained to national education systems. One of the most talked-about providers of charter education in the developing world, Bridge International, employs Accountability ICT at arguably the core of its classroom management model,

12 World Bank, "Education Management Information Systems."

http://datatopics.worldbank.org/education/wDashboard/dqemis

13 The very first project with an EMIS focus listed alphabetically - Afghanistan's P160567 - has a total project cost alone of 628 million. Thus to meet the 3 million USD threshold the project would need to spend a little less than half of $1 \%$ on EMIS-related activities. Even in smaller countries, Haiti's P155191 (which seems to be primarily about EMIS) is a 30 million USD project, St. Vincent's P154253 is a 10.7 million USD project.

14 This is taken from Technavio's 2017 Global Student Information System Market 2018-2022 report. While the report is proprietary, in a public Businesswire story Technavio includes a graph indicating incremental growth of 3.771 billion USD from 2017-2022 at a 16\% compound annual growth rate; the 3 billion base and 7 billion 2017 projection are ballpark figures based on these numbers. Businesswire story at https://www.businesswire.com/news/home/20180518005669/en/GlobalStudent-Information-System-Market-Grow-16; graph as downloaded at https://perma.cc/BQU6SYEA.

15 U.S. Government. "U.S. Government Strategy on International Basic Education, FY 2019-2023.” https://www.usaid.gov/sites/default/files/documents/1865/USG-Education-Strategy FY20192023 Final Web.pdf

16 Park, Jonghwi. "Master Plan Needed for ICT in Education.". https://www.globalpartnership.org/blog/master-plan-needed-ict-education; permalink at https://perma.cc/327T-645

17 UNESCO, "Support for ICT Master Plans is the official strategy of UNESCO's Asia-Pacific Bureau as of 2017."

http://www.unescobkk.org/fileadmin/user upload/ict/Workshops/amfie2017/UNESCO Regional Strategy AMFIE 2017.pdf 
precisely because its basic solution to the governance, accountability, and management challenges of running an education system is to maximize observation and accounting-based accountability. Teachers at Bridge schools deliver lesson scripts composed by master teachers who have likely never seen a given teacher's school or students. This script includes the precise words the teacher should say, prompts them to pause where master teachers believe appropriate, and instructs them as to how long each sub-topic is to be discussed. It instructs teachers when to make eye contact with students and when to snap their fingers to draw students' attention. As a teacher goes through her day the tablet will record detailed usage information with every tap of the screen and transmit this information back to Bridge management. Bridge is no fly-by-night operation; Bridge claims to have reached over 500,000 students in the half-dozen countries in which it works. Bridge boasts investors including the Chan Zuckerberg Initiative, Bill Gates Investments, the Omidyar Network, the World Bank's International Finance Corporation, and leading venture capital firms including Pershing Square and Khosla Ventures. ${ }^{18}$

The "I" in Accountability ICT is for information. The classic principal-agent model frames information asymmetry (what the boss doesn't know regarding what's happening on the ground) as a central concern in management, and Accountability ICT seemingly reduces these information asymmetries. But an ICT tool can only reduce asymmetry regarding the data (indicators, targets, administrative data, etc.) that enter the ICT tool, and thus that are available in a data dashboard or EMIS report or Bridge school monitoring database.

Accountability ICT reduces information asymmetry regarding those things that can be observed, verified, quantified, and reported. Thus, Accountability ICT works primarily by strengthening accounting-based accountability. Whether in any given interaction with a child a teacher was kind, or concerned, or inspiring, or raised the child's confidence is - these might be the central elements of a successful education system yet none of these are the included in the "I" in ICT.

The fact that Accountability ICT works via accounting-based accountability is useful for our analytic purposes, as it allows us to gain some purchase on the systemic effects of accounting-based accountability solutions by exploring whether changes in the availability, or cost, or penetration of ICT have been associated with changes in education system quality and/or proved historically to be binding constraints on education system performance. For example, is the rapid acceleration and falling cost of computing power, often summarized using "Moore's Law", in fact associated with changes in education system performance? If Accountability ICT is a core part of many attempted accounting-based accountability solutions, and there are indeed many attempted accounting-based accountability solutions, then we should expect system performance to be tractable to Moore's Law. If, however, a given activity is "Moore's Law resistant" despite many attempts to strengthen accountingbased accountability using ICT, we can take this as suggestive evidence that while technology may make productive improvements, it is unlikely to substantially transform the effective

18 This paragraph is drawn from Bridge International Academies' website, http://www.bridgeinternationalacademies.com, Ross 2014, Pilling 2017, and also from Chapter 2 of Honig's 2018 book, Navigation by Judgment. 
production possibility frontier. The next two sections explore the relationship between technology and system performance in education (Section III) and beyond (Section IV), as a way of exploring not just Accountability ICT narrowly but the relationship between accounting-based accountability and system performance more generally.

Our argument is not that EMIS systems are pointless or totally irrelevant. The accounting of keeping track of desks (and other thin inputs) and their allocation across classrooms and schools is a necessary and routine part of what any organization does. And perhaps EMIS can provide some modest efficiency gains in the management of thin inputs and in the expansion of enrollments. But since education is at its heart a "thick" activity EMIS and other ICT driven accounting driven tools are unlikely to lead to improved learning outcomes.

\section{Section III. Accounting-based Accountability and ICT, as Seen through Historic Evidence on Education Systems Improvement}

We believe that Accountability ICT is unlikely to lead to large improvements in accountability and thus system performance. But we could, of course, be wrong. We could be wrong in the sense that we are directly wrong about Accountability ICT: that is, greater use of Accountability ICT may improve performance. This might be because accountingbased accountability improves performance; it could be because Accountability ICT provides data that strengthens account-based accountability, not just accounting-based accountability; it could be something entirely different, because we misunderstand the causal channels entirely via which Accountability ICT operates.

We could also be wrong in that technology penetration could also lead to substantial improvements in education system performance but not via improvements in accountability. That is, ICT could assist as a productive input. Productivity gains that result from improvements of the technology in the production process itself (e.g. the invention of new superior inputs or processes) need not work via improved accountability. Putting technology into classrooms (e.g. giving each child a laptop) may directly enhance the student experience, producing better results through a channel largely unrelated to governance and accountability concerns. While we think there are lovely cases of technology enhancing education, our view is these are unlikely to be transformative at the systems level, as they are likely to abut governance constraints that limit the scope of their impact. But, again, we could be wrong.

If we are wrong in either of the senses above, then ICT penetration ought be linked to improvements in education system performance. If ICT penetration improves performance, we can presume that either 1) current accountability and governance arrangements are not the primary binding constraints (that within current governance equilibria, improved technical processes can lead to better results) or 2) that Accountability ICT can directly address governance problems, shifting "out" the constraints and thus leading to better performance. If, however, ICT growth is not associated with improvements, this is 
suggestive of the need to focus on non-logistical, non-contractible governance arrangements - and on something other than the accounting-based accountability that ICT can strengthen-in education systems improvement.

In 1965, Gordon Moore noticed the very rapid increase in transistors per integrated circuit, conjectured this would continue, and asserted what is now known as "Moore's Law": components per chip would double roughly every two years. This rate of progress has remained roughly stable (though it may have slowed recently) and hence since 1960 there has been roughly 9 orders of magnitude improvement (Figure 2) ${ }^{19}$. A change this large, of 8 to 11 orders of orders of magnitude is almost impossible to imagine. I am two meters tall. Even two orders of magnitude taller than and I am twice the Statue of Liberty (93 meters) and 8 orders of magnitude taller my head touches the moon. Driving at 70 miles an hour is common but one cannot go eight orders of magnitude faster as that would be faster than the speed of light.

\section{Figure 2. Gordon Moore's Law has persisted for 50 years}

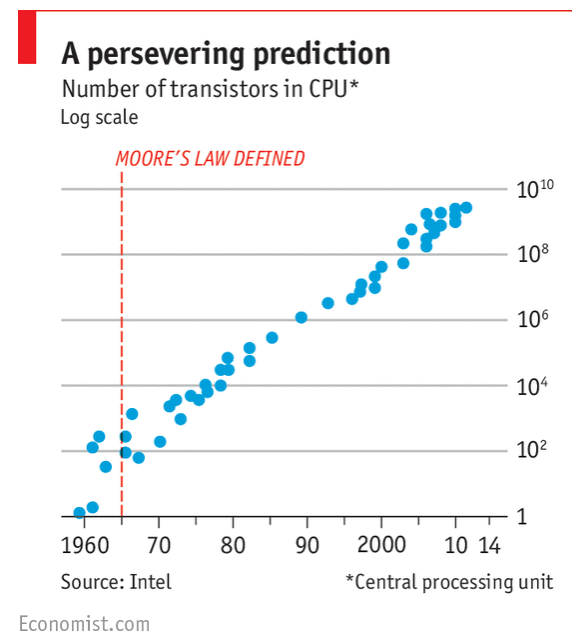

So transactional speed has improved massively, and the cost of that speed on a per unit basis (however you think of units-calculations, or the machines that make the calculations) has plummeted. These changes have allowed more calculating power, more machines, and more penetration of ICT. The pace of improvement has been pretty steady since the early 1960s, has been going on for 50 years, and may have slowed down recently (post 2006). Hence, the current phenomenal pace of improvement in ICT is not a new phenomenon. Collectively, we already have lots of experience with the implications of improvements in ICT and their consequences. We would do well to learn from these previous experiences.

\footnotetext{
${ }^{19}$ Of course, there are improvements in other elements of computing besides transistors per chip, and so total “calculations per second per $\$ 1000$ " has improved by at least 9 and maybe by as many as 11 orders of magnitude since 1960. This has meant the price of computing power has also plummeted by similar orders of magnitude (Nordhaus 2007).
} 
Given the magnitude of changes to date one thing we can easily learn is which activities are "Moore's Law amenable" and which activities are "Moore's Law resistant." As Appendix I details Moore's Law has led to massive increases in productivity and reductions in cost per (quality adjusted) unit in products like televisions (Moore's Law amenable) whereas there has been almost no change in the productivity of "child care." The question is whether learning outcomes in basic (K-12) education is, through either accountability or other paths, a Moore's Law amenable activity.

Across the OECD there has been (roughly) zero improvement in measured learning. Very few countries maintain data on student assessment that is comparable over long periods, but one of those countries is the United States, whose National Assessment of Education Progress (NAEP) has maintained comparable estimates of the reading ability of 17 year olds since 1971 and of mathematics since 1973. One of the most striking facts in education is that the reading score of 17-year-olds in the USA changed from 285 in 1971 to 287 in 2012. While the exact numeric scale of learning assessments is arbitrary and can be normed in any way, a common way to discuss changes in performance is to divide the change by the standard deviation in the assessment across students. The NAEP scale standard deviation is about 40 (so in a Normal distribution about 68 percent of students would fall between $287+40=327$ and 287 $40=247)$. This means over the 41 years of measurement, scores improved by $1 / 20^{\text {th }}$ of a standard deviation, which is, statistically speaking, nothing, as one cannot statistically reject the hypothesis that the average performance of a 17-year-old assessed in 1971 and one assessed in 2012 was the same (though the average score is affected by the very substantial shifts in demographic composition over this period).

This leads to a graph (figure 3) that is deeply insightful, or silly, or both: to plot Moore's Law progress and progress in learning over time. One has to use a log axis (powers of 10, orders of magnitude on the vertical axis) to even put the two on the same graph. The obvious point is that ICT, proxied by transistors per chip, has improved by (at least) six orders of magnitude since 1971 and learning has not only not changed by a single order of magnitude (factor of 10), it hasn't changed even by a factor multiple (say, doubled, factor of 2), it hasn't changed at all. 
Figure 3. Since 1971 transistors per chip has increased by 2 million fold; reading ability of American 17 year olds is unchanged

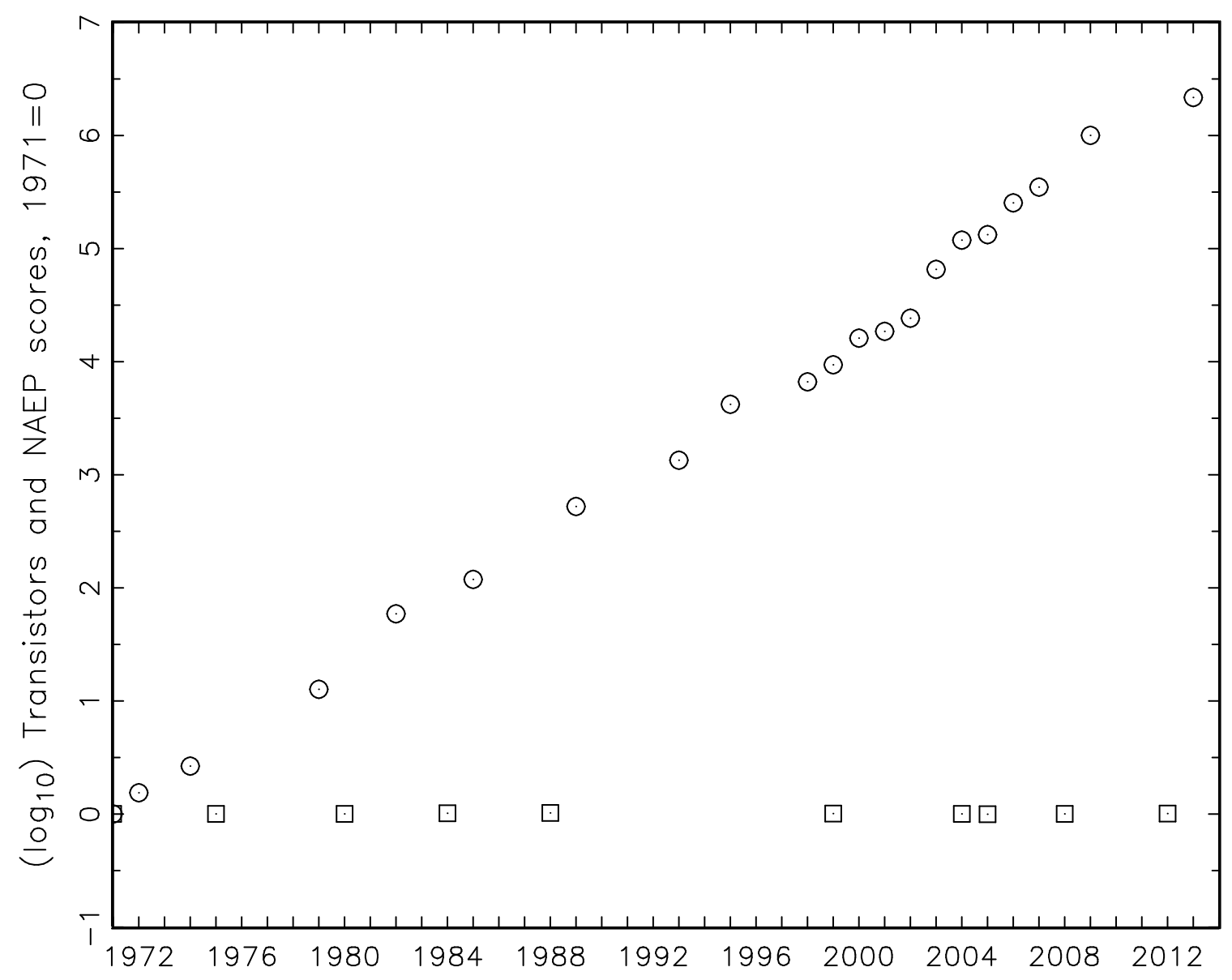

Sources: Our world in data for transistors per chip, NAEP long-term assessment for reading scores (https://www.nationsreportcard.gov/ltt_2012/summary.aspx)

Before this turns into a discussion of the parlous state of American education, what is true of the USA is (roughly) true of all other industrial countries. Gundlach, Woessmann and Gmelin (2001) noticed that the US both had the NAEP, a long and consistent assessment of certain learning skills, and that the US had participated since the 1960s in assessments that compared countries. This allowed them to create a measure of performance over time for countries by benchmarking their performance relative to the USA over time. Their conclusion (for 1970-1994) was that learning performance in most OECD countries was also, at best, stagnant, a conclusion that has broadly remained true in the more recent PISA assessments in the OECD. So, while, say, Japanese kids do much better than US kids in international assessments, they do so today by about the same amount (by the scale of the assessment) as they did in the 1970s. While better in absolute terms, their trend is also stagnant. 
For India and Indonesia, for which we have pretty reliable measures for over 10 years, the learning performance at each grade level appears to be falling (ASER, 2015, Beatty et al, 2018). And, using the few developing countries for which we have data on international assessments over time, we find that many have deteriorating performance and the typical gain per year is very small (about 1 point per year on an assessment with a student standard deviation across the OECD normed to be 100) (Pritchett and Beatty, 2012; Kaffenberger, 2019).

While any given set of facts is consistent with a wide array of causal interpretations, the performance on learning assessments of teenagers in the OECD is about the same as it was forty years ago, while ICT has improved by at least six orders of magnitude. This strongly suggests that teaching and learning are Moore's Law-resistant activities, with the binding constraints on improvement having little to do with the speed or availability of processing power.

Countries today, at today's level of technology, are behind where the USA was in 1971. If we combine the fact about the stagnation of learning performance of US students since 1971 (and of other OECD countries) with the comparisons of the current relative performance of developing countries we see that since (a) many developing countries are very far behind the USA today and (b) the USA is not ahead today of where it was in 1971. This implies that (c) many developing countries have much worse learning performance than the USA did 45 years ago.

The obvious implication is that it was demonstrably possible at the levels of ICT available in 1971 to create and sustain education systems with learning performance far above the current levels in Indonesia or Brazil. While this need not mean that ICT, or Accountability ICT, or accounting-based accountability cannot be transformative in developing countries today, it is compelling to note that ICT is obviously and demonstrably not a necessary input for education systems to function at a level that would represent a massive improvement over much of the developing world today.

Limited results of accounting driven approaches in the US A. Where accounting-based accountability has been used as the primary means of service improvement in developed-world contexts where we might expect the penetration of technology to be most likely to succeed. In Tyranny of Metrics (2018), Jerry Muller describes the US experience under the Bush-era "No Child Left Behind" (NCLB) program, an attempt to drive better educational outcomes via accounting-based accountability's push for "measurable results." The result? Higher test scores for some-but no evidence of improved learning outcomes. The Obama administration's solution to NCLB's failings was more accounting-based accountability for schools via the metrics-laden "Race to the Top," which extended accounting-based accountability to teachers. The result of all this effort? Very little evidence of improved system-wide improvements, or the closing of the achievement gap between white and nonwhite pupils.

Closing the achievement gap is, of course, a laudable aim. And the metrics created to achieve this aim are, in our view, sometimes useful in diagnosing problems: we believe concepts like 
"teacher value-added" are useful, and help focus attention on the classroom experience where learning actually occurs. But the question is not whether accounting-based accountability systems help us understand the world; it is whether these systems improve the outcomes they seek. The evidence that they do is, to date, scant at best. It is telling that for some advocates of accounting-based accountability, the problem is that there still isn't enough; that if only teachers unions could be broken, and firing and hiring more tightly linked to accounting-based accountability, then we would see the improvements. It seems that advocates of accounting-based accountability can always reason that the failing is because the measures taken are not enough. Is this logically possible? Certainly. But evidence to date suggest it is unlikely.

\section{Section IV. Technology, Governance, and Productive Limits Far Beyond the Realm of Education}

Technology is no longer the limiting factor in education as regards management and accountability. Indeed, it seems unlikely it ever was, in the USA or anywhere else. We think of the most important parts of the management of education systems as a Moore's Lawresistant activity. This section IV suggests that section III's pattern is more general; that public governance activities may be largely Moore's Law-resistant. We also suggest that technology's benefits as a productive accountability input even in the private sector is, while far from zero, commonly over-estimated.

- Governance more broadly is not Moore's Law amenable; Indicators of aggregate state capability show deterioration in more than half of developing countries over the 1996-2015 period.

In Building State Capability, one of us (Pritchett, with Matt Andrews and Michael Woolcock) tried as best we could to produce data about the level and evolution of the organizations and agencies of developing country governments to implement policies and programs. The book develops a defensible measure (drawing on the many different cross-country ratings and rankings) from 1996 to 2012, which is only 16 years but at least gives some indication of growth. That data had three striking findings. First, 70 of the 102 developing countries with data experienced negative growth in state capability over this period. Second, almost half (49 of 102) of the countries have "weak" or "very weak" capability—on a very loose definition of "weak" - and of these, 36 had experienced negative trends since 1996. Third, only 13 of the 102 countries were on a trajectory to have "strong" capability (measured as the capability of weakest of the industrial countries, e.g. Portugal, not strongest) by the end of the $21^{\text {st }}$ century.

Perhaps the growth of processing power and penetration of ICT can play some role in improving organizational capability, but the best that could be said is that, despite high and rapidly growing levels of ICT over this entire period and numerous efforts that attempted to use ICT, governance isn't improving yet in most places.

- Can we find evidence that Moore's Law-amenable accounting-based accountability is the binding constraint, even where that seems most likely: in the developed-world private sector? 
Standard measures of the growth of economy-wide productivity (TFP) in leading countries have slowed down, massively. While the pace of technological change and concomitant societal penetration of ICT processing power had been extremely rapid, the standard measured rate of growth of total factor productivity, the aggregate measure of how much output has increased for a given magnitude of capital (human and physical), in the 20 most advanced economies is now less than a third of what it was 50 years ago. From 1950 to 1970, it was growing at 1.52 percent on average and from 1990 to 2014 it grew at only .36 percent-a quarter of its earlier level.

Table 2. The annual rate of growth of measured total factor productivity (TFP) in the top 20 most productive economies in $\mathbf{1 9 7 0}$ has fallen to less than a third of its previous level

\begin{tabular}{|l|r|r|r|r|r|}
\hline & \multicolumn{2}{|c|}{ Per annum TFP growth } & Change in TFP growth & \multicolumn{2}{l|}{ Ratio TFP growth 1990- } \\
& $1950-$ & $1970-$ & $1990-$ & $1990-2014$ versus (1950- & 2014 to 1950-1970 \\
& 1970 & 1990 & 2014 & $-0.91 \%$ & 0.30 \\
\hline Median & $1.36 \%$ & $0.55 \%$ & $0.41 \%$ & $-1.16 \%$ & 0.24 \\
\hline Mean & $1.52 \%$ & $0.47 \%$ & $0.36 \%$ & &
\end{tabular}

Source: Author's calculations with TFP in Penn World Tables 9.0 (Feenstra, Robert C., Robert Inklaar and Marcel P. Timmer, 2015)

A central argument of Robert J. Gordon's masterful The Rise and Fall of American Growth (2017) is that if one calculates TFP growth for the American economy and breaks the span from 1890 to 2014 into three periods - 1890-1920, 1920-1970 and 1970 to 2014 - it is only the middle 50-year period of 1920 to 1970 in which TFP growth was rapid. "TFP growth in the 1920-1970 interval is stunning, being almost triple the rate of growth in the two other periods." (Gordon 2017, p 16). Gordon's argument is that the technological and organizational changes in the 1920 to 1970 period affected many industries but many of these were "once off" and cannot be extended (e.g. the move to indoor plumbing, the advent of air conditioning, or introduction of the automobile) whereas innovation since 1970 has "excelled in the categories of entertainment, information and communications technology" (Gordon 2017, p 642) but has not had the same kind of broad transformational effects on other industries.

Defenders and promoters of ICT can argue that TFP mis-measures the consumer surplus gains from ICT and hence TFP is the wrong measure-but TFP has always mis-measured consumer surplus gains, and hence this doesn't necessarily create a case the gains from ICT are understated by current methods.

So when people say "technology is changing faster than ever" they often just mean "the penetration of ever-cheaper processing power is continuing its rapid expansion." But the puzzle for economists about economic growth is why it has slowed in the leading countries, and why it has slowed by so much. We don't need an explanation for why the impact of technological progress is causing economic growth to accelerate: it isn't accelerating. The fact is that the continued rapid pace of improvement in ICT has not been associated with accelerated economic growth in aggregate, nor has it associated with an accelerated pace of 
the standard measures of TFP. This strongly suggests that Accountability ICT and by extension the current limits on accounting-based accountability are not a binding constraint preventing performance improvements from being realized.

There are also private-sector parallels to the argument we are making about Accountability ICT. As Carlile (2019) put it in a discussion of MRP, ERP, and CRM ${ }^{20}$ in private sector settings, "When technology leads it nearly always runs over the organization with problematic results. It is always about the organization first and technology second; it is about the existing organization and how can we use technology to improve it." 21

- The historic US experience, in comparison to the contemporary state of the developing world, does not suggest improvements in account-based accountability is likely to improve governance.

In section III, we suggested that a comparison of the historic American level of educational attainment with modern developing countries strongly suggests that technology is not the binding constraint on education. The same might also be said of economic growth more broadly. That is, figure 4 suggests the USA achieved GDP per worker levels in the preelectronic computing age (1950) factor multiples higher than developing countries have at present.

\footnotetext{
${ }^{20}$ Material/manufacturing Resources Planning, Enterprise Resource Planning, and Customer Relationship Management, respectively.

${ }^{21}$ Personal communication/comment on an earlier draft of this paper, Carlile to Honig \& Pritchett, February 20 2019.
} 
Figure 4. Ratio of real GDP per worker in countries in 2014 to that of the USA in the pre-electronic computing era (1950) (all developing countries with population $>30$ million)

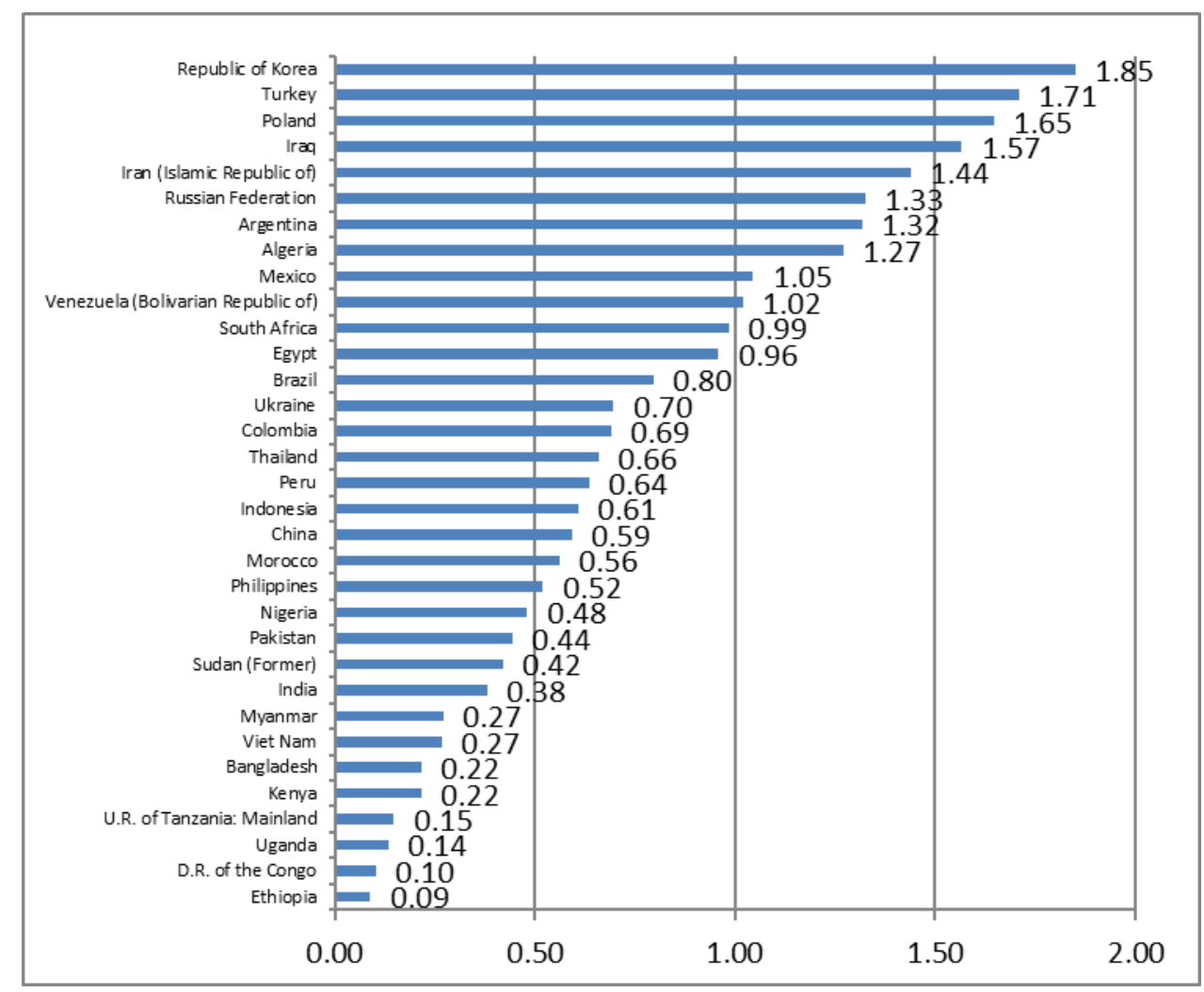

Source: PWT9.0, Feenstra, Inklaar and Timmer (2015)

While people often compare the output per worker across countries, an obvious but conceptually important fact is that countries that have low productivity (output per worker) today have low productivity compared to the productivity not just of the USA today, but of the USA in the distant past. US GDP per worker (in 2011 PPP) in 1950— prior to the advent of the impact of electronic computing or widespread use of integrated circuits —was US\$36,190. The obvious point is that at the technology of 1950 this level of output per worker was achievable. The GDP per worker of the bottom 25 percent of countries in the world is only around US $\$ 11,000$ - less than a third of that. In 2014 , even after a very spectacular extended burst of rapid growth, India was at less than 40 percent of the output per worker of the USA in 1950. The very obvious implication is that modern computing and its ancillary technologies played (roughly) zero role in achieving the high levels of productivity in the now-developed economies.

So what do we learn from sections III \& IV? First and foremost, it appears governance, accountability, and management improvements seem to be largely Moore's Law resistant activities, in education and far beyond. We ought have known that by thinking about the production process. But the data is also consistent with this conclusion. That is: 
- Looking at today's high-performing countries, technological limits on accountingbased accountability did not prove to be a binding constraint that precluded high levels of system performance.

- Examining recent trends there are no signs that Moore's Law changes have led to improvements in education, or state capacity more broadly, again suggesting that the technological frontier's limiting of accounting-based accountability plays little to no role in limiting or enabling progress on governance, accountability, and management improvements.

- This is not because the public sector is different than the rest of the economy. It seems more likely than not that in the broader economy, processing power and penetration is not the present binding constraint to productivity growth. If it were, we would expect growth to continue to rise as processing power increased. It has not.

This set of stylized facts ought give us pause, and suggest the question to be framed not as "Where-e.g. education — will accounting-based accountability not lead to massive improvements?" but rather "Where—and why—are the relatively few places where technology will lead to massive improvements by improving accounting-based accountability?"

Is this story is incomplete? Yes, of course; this is not a full description, or even a very substantial partial description, of what has happened in the broad space of education and governance in the past $50+$ years. That said, we have no evidence that the technology revolution (which is far from new, but rather a continuation of prior rapid improvements in technology) has led to improvements in accountability systems, or improved performance of education systems. Not only is tech not sufficient; there is also good reason to believe ICT is not necessary for high-functioning accountability systems in public education, drawing on the historic experience of today's developed countries. What is true of the education sector also seems to be broadly true of the public sector; education is not an outlier but rather an "in-lier". Accounting-based accountability's availability seems to play about the same role as does the success of Dan's beloved Detroit Tigers in global systems improvement via governance, accountability, and management reforms: that is, no role whatsoever.

In regard to education, we have argued that ideas about the role of ICT in education take one of two forms. One is that ICT will help manage the system by creating up-to-date, accurate data that can guide decision making or perhaps improve accountability via what we are calling Accountability ICT. The other is that ICT makes possible superior modes of pedagogy despite the current governance constraints. ${ }^{22}$ Either argument suggests that greater

\footnotetext{
22 While our primary focus in this paper is accountability not ICT, our theory and suggestive evidence do not lead us to a position of no hope for any use of technology in education. On technology as an input to students, there are many indications that merely placing technology in students' hands is no panacea. (E.g. Organization for Economic Co-operation and Development, 2015 or Cristia, Ibarrarán,
} 
penetration of technology should be associated with greater education system performance. Reviewing historic and comparative evidence on technology's cost and penetration, we see basically zero association between technology penetration and learning improvement. We believe this historic data matters, as - contrary today's reification of a supposed technology revolution - there is little evidence that technological development or penetration has been particularly rapid, or likely to be transformative, in recent decades as opposed to e.g. the 1960s-1980s.

We are far from the first people to say "technology is no silver bullet" in education, or governance. Sir Michael Barber-who is often associated with a focus on data and delivery — has written that "For years — ever since the 1970s — we have heard promises that technology is about to transform the performance of education systems. And we want to believe the promises; but mostly that is what they have remained. The transformation remains stubbornly five or ten years in the future but somehow never arrives." (Fullan and Donnelly, 2013)

We do believe there is a place for data-gathering systems, and for ICT—and possibly even Accountability ICT - to play a productive role. But we ought not to expect that ICT, and particularly Accountability ICT, will be transformative (in Appendix II, we lay out a more formalized version of this argument for those who prefer their argumentation with greek letters). Essentially, we think it implausible that the broad pattern of facts we have outlined above are consistent with Accountability ICT being a major source of transformation, but that simply not yet being reflected in the data.

The "facts" above are not "facts" like "gravitational acceleration is (about) 9.8 meters/second squared" is a fact, but are by no means fake news, either. Does the evidence we have presented prove that ICT won't work, or that Accountability ICT is the wrong place to focus in education? No, of course not. It is possible that there is some transformative technology in either the pedagogical or the Accountability ICT sense that did not exist in the past but has newly emerged. Even if the frontier of technology is not moving forward more rapidly, it is possible that it has newly unearthed truly game-changing innovation for education systems. We in fact hope this is the case, though we think it unlikely.

The vast expansion in computing power has vastly increased the ability to store, transmit, and analyze information. There are two broad ways we could imagine that this might help transform education specifically, and state capacity to deliver welfare-enhancing services more broadly. The first is as an input: a technological complement that increases productivity. The second is by changing the information processing of organizations, including bureaucracies, and thus the ability of "thin" accounting based accountability. We see no evidence whatsoever that there are substantial performance improvements associated

Cueto, Santiago, and Severín, 2012) That said, recent rigorous evaluation in Delhi of Mindspark, an ICT-enabled adaptive learning program, finds impressive results (Muralidharan, Singh, and Ganimian, 2016). The notion that questions more adapted to students' abilities may be useful, particularly in classrooms with massive variation in students' abilities, makes quite a bit of sense. 
with the generalized growth of technology, nor do broader state capacity measures in the developing world move in concert with ICT's penetration. The historical record of today's developed countries also suggests that the absence of information-processing enabled accounting-based accountability was not a binding constraint, historically speaking.

This is not for lack of trying. The country-level experiences of introducing accountingcentered Education Management Information Systems (EMIS) has had mixed results, at best. India has introduced a massive, award winning, EMIS system to collect data of the accounting type: enrollment, age of teachers, etc. While the implementation of the system itself has been widely praised, it is widely accepted that the quality of public schools deteriorated over exactly this period (Pritchett 2014). Several researchers suggest instead that the demands of "feeding the beast" turned local Indian administrative workers, intended to be responsible for improving teaching and learning, into "post office workers" who mainly collect data they themselves regard as irrelevant (e,g, Aiyar and Bhattacharya 2016).

American financial services firms incessantly tell the public that "past performance is not a guarantee of future results"; and that is of course possible as regards Accountability ICT and accounting-based accountability solutions in education. But any model or theory that predicts rapid departure from historical trends ought have to pass a high burden of proof before being worthy of substantial investment. "Investors"-private firms, foundations, institutional donors, etc.—are not treating Accountability ICT’s accounting-based accountability theory of change as if it is the unlikely 'longshot' solution, the one which needs to pass a substantial burden of proof. Instead, technology-enabled solutions seem to face a lower burden of proof in the marketplace of ideas, and that of startup funding; this seems inappropriate. Anyone advocating for the transformative power of educational technology ought to need to explain why, in fact, this time is different.

Is the kind of accountability essential to creating and sustaining systems of education focused on broad-based, equitable, learning enhanced by Accountability ICT, which has vastly expanded the ability to do accounting? No, it isn't. Education systems (and the shift towards education systems that are coherent around equitable learning as a key goal) need account-based accountability that is supported by, but neither focused on nor exhausted by, accounting. So how do we get there?

\section{Section V. Accounting-Based Accountability as Input not Answer}

The Robert Kennedy quote which opens this paper reminds us that Gross National Product is national accounting. We might say, extending RFK's wisdom, that any form of accounting defined as an attempt to reduce phenomena to objective, cardinal rankings, can measure everything "except that which makes life worthwhile." Accounting is thin, not thick; most appropriate for balancing the books, rather than forming the foundation of accountability for myriad educators distributed around the world.

High-performance education systems require quality teaching, and quality teaching is not reducible to accounting. For a simple thought experiment, think of the best teacher you ever 
had ("best" is up to you to define-perhaps you thoroughly learned the subject being taught, were most inspired by, built your character, taught life lessons) and write down their name.

Now, think of the worst teacher you ever had and write down their name. Now, imagine you are creating a data base of objective information that can be measured by cardinal numbers. Can you come up with the kind of accounting data that large schooling bureaucracies, or any kind of centralized top-down system, could use to distinguish between those two teachers?

The more technical counterpart to this thought experiment is that evidence of the "learning value added" (the increment to measured student learning of having a particular teacher) of teachers (and this is really hard to do well; it has really only been done in the USA and more recently Pakistan) shows that (a) learning value added varies widely across teachers but (b) learning value added of teachers is not explained by standard thin "observables" (read: Accountability ICT-amenable) characteristics.

Even where accounting-based accountability seems to work, it may be a kind of pyrrhic victory. We introduced two kinds of cases of Accountability ICT in Section II; EMIS systems and Bridge Academy's classroom management system, which has an echo of the cameras in classrooms teacher attendance intervention with which this paper opened. We believe it is possible there will be some improvements as a result of the accounting-based accountability these technologies induce, but of a particular sort. A teacher of very, very low competence may well be better off being tightly controlled by a script. An EMIS system may well help identify where students or teachers are absent. Both these examples of accountingbased accountability may well raise the floor on teaching and learning. In this sense, both are laudable; making the worst teachers, schools, etc. less bad is certainly an improvement. But, as one of us has written in a book title, "Schooling Ain't Learning." Raising the system's floor is not the same as transforming the system.

There are good reasons to worry that a focus on accounting-based accountability may not just be neutral, but actually detrimental, to system-wide performance. The multitasking problem in economics (Holmstrom and Milgrom, 1991) suggests that if people working in the education system invest time in collecting what can be measured and reported, they will do so by investing less time in what cannot be as easily accounted for-like teaching quality, individual instruction, relationship-building, responsiveness to parents or other teachers, etc. (Aiyar and Bhattacharya, 2016). If reporting becomes a tool of control, it can constrain teacher autonomy, leading some of the best teachers to exit. Top-down control using accounting-based accountability channels may also demotivate teachers from learning about their students if the teachers cannot make productive use of that information, in an echo of Aghion and Tirole's (1997) tension between real and formal authority.

Part of account-based accountability is building common understanding and trust. A primarily accounting-driven approach can undermine that trust, as managers and agents both focus on delivering the numbers and process compliance, rather than the broader purpose of the organization. As US Secretary of Defense Stimson (1945) put it "the only way you can make a man trustworthy is to trust him; and the surest way to make him untrustworthy is to distrust him and show your distrust." This is vanishingly close to Mansbridge's (2014) argument that a reward and punishment regime based on external monitoring "Not only 
stems from distrust; it creates distrust." Empirical work suggests that Stimson and Mansbridge are correct, with accounting-based accountability associated with reduced motivation. (e.g. Moynihan and Pandey 2007, Belle and Ongaro 2014) This holds for development projects; in Navigation by Judgment, one of us (Honig, 2018) describes the damaging effects that result when accounting-based accountability crowds out agent judgment and freedom to be accountable in thicker, account-based ways.

Managing civil servants with primarily or exclusively via accounting-based accountability may be demotivating for those who remain, and lead to exit of the differentially positively motivated. The choice to primarily employ accounting-based accountability as a reform strategy, then, requires careful consideration of the potential costs for employees. One such cost is the potential to induce the transformation of agents from intrinsically motivated employees (McGregor 1960's Theory Y; see Table 1) to employees who indeed will shirk in the absence of monitoring (Theory X). Accounting-based accountability can be a kind of self-fulfilling prophecy, creating the problem it is meant to solve.

We have not yet discussed attempts to use technology to strengthen horizontal or bottomup accountability, rather than the top-down accounting-based accountability we have stressed thus far in this paper, sometimes known as "civic tech". We believe that the civic tech literature is consistent with the broader thrust of our argument, and also suggests a way forward: that technology may be a useful complement to a governance program, but that the mere creation of more information and even more transparency will not naturally translate into governance improvements. Fox (2007) calls this "The Uncertain Relationship Between Transparency and Accountability." The mere existence of data will not lead to accountability unless that data is used to make institutions "answerable," or better yet, if those using the data can sanction or compensate those they are attempting to hold accountable.

As the excellent final synthesis report for the USAID, DFID, SIDA, and Omidyarsupported Making All Voices Count project - which aimed to "harness the power of new technologies to make government more effective and accountable"-put it, "technologies can play decisive roles in improving services where the problem is a lack of planning data or user feedback" (McGee et al, 2018, p. 9). When it comes to attempts to "build the foundations of democratic and accountable governance systems", however, the study finds that "the kinds of democratic deliberation needed to challenge a systemic lack of accountability are rarely well supported by technologies" (McGee et al, 2018, p. 16), and "technologies alone don't foster the trusting relationships needed between governments and citizens, and within each group of actors" (McGee et al, 2018, p. 18).

This is further evidence that accounting-based accountability is more appropriate as a complement, not a substitute, to account-based accountability. Evidence and theory suggests that ICT's productive role comes not when Accountability ICT is seen as "the answer" but when technology is used to complement a larger governance intervention that maps onto a nuanced understanding of local contexts, voices, and power. This does not mean abandoning ICT as a potential tool, but shifting away from seeing the mere generation of data as a primary pathway to substantially improved system performance. 
While change cannot be catalyzed by accounting-based accountability, that does not mean that accounting- and account-based accountability cannot be complements. Table 3 attempts to describe some of the accounting-based and account-based accountability practices we think typical of different types of firms. 
Table 3. Stylized accountability regimes in different, relatively successful, organizations

\begin{tabular}{|c|c|c|c|c|c|}
\hline & Type of Accountability & \multicolumn{4}{|c|}{ Model Organizations } \\
\hline & & $\begin{array}{l}\text { US Army (and possibly any } \\
\text { effective army) }\end{array}$ & Dentist's Office & Post Office & Elite University \\
\hline \multirow{2}{*}{$\begin{array}{l}\text { Accounting- } \\
\text { based } \\
\text { Accountability }\end{array}$} & $\begin{array}{l}\text { Focused on process } \\
\text { compliance and counting } \\
\text { inputs }\end{array}$ & $\begin{array}{l}\text { Yes; need to engage in } \\
\text { accounting for inputs, and } \\
\text { following "rules and regs." } \\
\text { Reported both to } \\
\text { organizational management } \\
\text { and "up" to Congress. }\end{array}$ & $\begin{array}{l}\text { Yes; professional standards, } \\
\text { state quality boards, etc. }\end{array}$ & $\begin{array}{l}\text { Yes; compliance focus } \\
\text { paramount, primary. }\end{array}$ & $\begin{array}{l}\text { Yes; need to follow procedures } \\
\text { with students, funds (e.g. grants } \\
\text { management), etc. }\end{array}$ \\
\hline & $\begin{array}{l}\text { Focused on measurable } \\
\text { outputs or outcomes }\end{array}$ & $\begin{array}{l}\text { Yes, where task measurable; } \\
\text { more frequent in peacetime. }\end{array}$ & $\begin{array}{l}\text { Yes; e.g. filled cavities as basis } \\
\text { of payment, reduced patient } \\
\text { pain, etc. }\end{array}$ & Yes; delivery tracking. & $\begin{array}{l}\text { Yes; publication incentives for } \\
\text { faculty. For org as a whole, } \\
\text { student graduation, } \\
\text { performance on grad } \\
\text { admissions exams, job market } \\
\text { placement }\end{array}$ \\
\hline \multirow{3}{*}{$\begin{array}{l}\text { Account- } \\
\text { based } \\
\text { Accountability }\end{array}$} & $\begin{array}{l}\text { "Thick" description of } \\
\text { process, outputs, } \\
\text { outcomes. }\end{array}$ & $\begin{array}{l}\text { Yes. To internal stakeholders } \\
\text { via after-action reports; more } \\
\text { frequent in wartime. To "top- } \\
\text { down" stakeholders (e.g. } \\
\text { Congress) via study tours, } \\
\text { hearings, regular } \\
\text { communications. }\end{array}$ & $\begin{array}{c}\text { Limited need for internal } \\
\text { description, given small typical } \\
\text { firm size. }\end{array}$ & Limited & $\begin{array}{l}\text { Yes; in grant proposals, } \\
\text { committees, and various other } \\
\text { internal and external fora } \\
\text { substantial description of } \\
\text { outputs and outcomes }\end{array}$ \\
\hline & $\begin{array}{l}\text { "Thick" description } \\
\text { directly to "clients" } \\
\text { (empowered 'users') }\end{array}$ & $\begin{array}{l}\text { Limited; some accountability } \\
\text { to families of those affected } \\
\text { by military action. }\end{array}$ & $\begin{array}{c}\text { Yes. Primary source of } \\
\text { accountability is continued } \\
\text { transactions with patients, who } \\
\text { have market power/can shift } \\
\text { providers. }\end{array}$ & Limited & $\begin{array}{l}\text { Yes; students as "consumers" } \\
\text { and clients }\end{array}$ \\
\hline & $\begin{array}{l}\text { "Thick" accountability to } \\
\text { voluntary associations and } \\
\text { identities }\end{array}$ & $\begin{array}{l}\text { Yes; soldiers as professional } \\
\text { identity. }\end{array}$ & $\begin{array}{l}\text { Yes; professional school as } \\
\text { inculcator of norms, } \\
\text { professional associations, } \\
\text { conferences, etc. }\end{array}$ & $\begin{array}{l}\text { Some; some } \\
\text { identification in e.g. } \\
\text { Postal unions }\end{array}$ & $\begin{array}{l}\text { Yes, for many groups; e.g. } \\
\text { faculty, administrators as } \\
\text { members of professional } \\
\text { networks }\end{array}$ \\
\hline
\end{tabular}


We began our discussion of organizations by noting that they are formed by human beings to achieve their joint purposes. The question of accountability is thus at its core a question of how those human beings ensure that one another and/or their agents are achieving the purposes of the organization to the greatest extent possible. In Table 3, the post office is arguably a successful purpose-driven organization whose primary accountability methods are accounting-based; this is perfectly appropriate, as the accountability technology is appropriate for the logistical tasks the post office primarily conducts.

But for organizations where tasks are not fully logistical in nature, accounting is a complement rather than the sole or primary focus of accountability. The US Army is a massive user of ICT, including Accountability ICT_-but this ICT is not itself meant to catalyze better performance. The Army is an organization with incredibly broad scale, which does require some use of Accountability ICT. But this accountability ICT is not the basis of accountability routines, nor is it used to kick-start accountability.

It is not that some firms have no accounting-based accountability; it is just that some firms put more pressure on these forms of accountability than others. It also is not the case that the line between accounting-based accountability and account-based accountability is the same as the line between reporting to certain kinds of people (e.g. politicians) as opposed to others (e.g. parents of students). Both account- and accounting-based accountability can be used for internal management and internal reporting. The differences between these firms are in terms of balance, of emphasis.

Levy et. al. (2018) in The Politics and Governance of Basic Education in South Africa provides vivid examples of the importance of account-based accountability, and how difficult this is to sustain. In their view, account-based accountability requires a change in broad cultures of accountability at the local level, a task that is highly Moore's Law-resistant and unlikely to be substantially catalyzed by improved technology. Levy also observes a kind of failure in which schools focus on control of thin inputs whether or not those produce improved learning outcomes - in our language, accounting-based accountability. So how to stimulate more account-based accountability?

We do not have a complete answer to this question. But a key element of Pritchett (2013) is extending the metaphor, borrowed from Bergstrom and Brafman (2006), of "spider" and "starfish" organizations to spider and starfish systems. The "spider" system tries to control and deploy all resources from the center. In contrast, a "starfish" relies on loosely coordinated local action. A starfish education system separates the various functions needed in an effective education system and keeps centralized those that are highly technical and with economies of scale (e.g. the design and implementation of system learning assessment). It pushes down the decision making in day-to-day teaching to the lowest levels possible. In that book, Pritchett argues one can stimulate "performance-pressured" starfish systems so there is adequate information about learning outcomes, but individual educational units are still free to create their own accountability systems to respond to those performance pressures. 
Spider-like organizations prefer accounting-based accountability, as it is the most easily scaled approach to accountability and has the lowest transaction costs. But it is far from the only possible solution to improved accountability and performance. Experiments (and other experiences) have shown that introducing even modest amounts of direct accountability from teachers to local communities via account-like mechanisms can have pretty substantial impacts on learning (Pritchett 2013). This is both through private sector-like "choice" mechanisms of accountability, and "voice" mechanisms of direct participation in decisionmaking.

In our tentative view, efforts to strengthen education systems are likely to be most successful when they combine the current (laudable) direction of emphasis on student learning-a focus on actual student achievement, pedagogical support, and innovative education techniques, including those that use ICT as an input-with a very different approach to solving education governance. This approach could focus on establishing bases of accountbased accountability, including:

- The creation of stronger relations between schools and their communities;

- The strengthening of local governance;

- The strengthening of horizontal professional networks and peer accountability for teachers and principals;

- The granting of greater autonomy to principals, in combination with more emphasis on learning outcomes;

- The highlighting and rewarding of positive deviants, principals and teachers that have performed exceptionally well within the system's current constraints.

None of these solutions is as easy to package in a development project as is an Education Management Information System (EMIS). The current equilibrium—-pushing technologyenabled solutions that we believe unlikely to substantially forward development in many domains - has obvious advantages to many actors involved in the transaction. It allows providers to have an "answer." When the World Bank gives a loan to a country so it can buy an EMIS, the World Bank can present a clear, cogent story as to what it has provided the government, and why the recipient government ought to take on a loan. The existence of a high-priced, modern technological solution allows development banks to sell something that can be understood both to buyers and to funders (e.g. the rich nations that finance the bulk of the World Bank's budget). The recipient government buyer, for their part, can appear "modern," a display effective in much the way a peacock's display of plumage is effective. That is, the government can show citizens and other countries that it is modernizing. It may even believe it, in the way car enthusiasts once extolled the virtue of tail fins and spoilers for their functional value. And, of course, the great number of firms that provide technical services creates entrenched interests in the development contracting ecosystem that have every incentive to continue to believe that the expertise they peddle (including, but not 
limited, to technology-enabled 'solutions') are likely to bring about transformative change, historic evidence to the contrary notwithstanding.

But the difficulty of packaging education governance and accountability solutions - and the fact that they may be more costly in time and sustained relationship building than they are in financial terms - ought not confine them to the rubbish bin. Projects and interventions that focus on account-based accountability construction rather than primarily on strengthening accounting-based accountability via ICT would spend more on people than goods. They would recognize that change is messy and non-linear, and that engagements ought be measured in years or perhaps decades, not months.

What is the alternative to Accountability ICT, and a focus on strengthening accountingbased accountability? Our answer is to focus on building locally embedded account-based accountability (both horizontally to peers and downwards to communities) in education, and beyond. Some, on reading this, may roll their eyes, imagining interventions unlikely to achieve scale. The scalability of accounting-based accountability is seductive; but it is a siren song that will often lead to shipwrecks on the long voyage of development. ${ }^{23}$ To rapidly implement at scale accounting-based accountability where it is ineffective, or even deleterious, is to accomplish nothing. In addition, to say that each intervention must be "deep" - digging into the governance particulars in every given setting — does not mean that it cannot be broad, too. That is, there is no reason that a push for more account-based accountability cannot be widely pursued in education reform initiatives throughout the developing world.

The focus on easily scaled solutions is tied to the idea that identifiable innovations (including, but not limited, to accountability innovations) can have forced top-down adoption, independent of a system with account-based accountability structures. The theory of change is essentially the same as making Kool-Aid from water: Open the packet, shake in the innovation from outside the system, and voila—an improved drink. All evidence is that the Kool-Aid theory of change hasn't worked very well for accounting-based accountability solutions in development or really anything else that is thin and thus holds the promise of rapidly reaching scale, with the exception of the most verifiable logistical tasks (e.g. delivering letters, or vaccines). Highly scalable accounting-based accountability solutions have not achieved, and are unlikely to achieve, very much; it is time to try a different path.

\section{Section VI. Conclusion}

The core take-away of this paper is not meant to be about cameras, or ICT, or Accountability ICT, or even education. It is about accountability. We think there are real stakes to how we think about accountability in development. What we talk about when we talk about accountability matters not just for education but also for the broader conversation regarding how development is pursued by national agencies, international actors, and the

23 The "long voyage" is a reference to Albert Hirschman's description of development as a "long voyage of discovery" (1967); the siren and shipwrecks is, of course, a reference to Odysseus' journey in Homer's Odyssey. 
broader development industry. Accountability is critically important to public sector performance and to sound management more generally, and thus is critical in improving systems (education, health, justice, transportation, commercial regulatory, tax collection, etc., etc.) that can have massive effects on human welfare. But somewhere along the way we collectively have lost the meaning of what accountability in fact is. The "patina of objectivity" (Espeland and Sauder, 2014) of accounting-based accountability is an illusion, a self-deception that often leads to the "the black hole of process compliance". (Levy et al, 2018)

This paper has focused on why our accounting-based accountability attempts at system reform in service delivery may sometimes drive us precisely in the wrong direction, using Accountability ICT in education as an example. Accounting-based accountability solutions solve the wrong problem, and do so in a way that further reinforces what we believe to be one of the larger misconceptions we see in the world of development practice today- the idea that the most fertile territory for answers lies in accounting-based accountability.

Much of what is currently fashionable in education reform assumes that external catalystsbe they reformers from the capital or outside agencies — are going to provide critical transformative inputs. We think this is unlikely, as it misunderstands both the nature of the problem (a governance and accountability challenge, first and foremost) and the most likely class of solution ("thickening" accountability relationships with focus to be on making an account rather than accounting). In our view neither all accounting nor all technology ought to disappear. Some of the metrics which are the focus of so much energy ought stay, but these would change their roles from providing answers to the question of accountability to acting as inputs to a broader process. Education systems capable of producing sustained results are built around thick accountability relationships that are coherent around learning as an objective use all information-"thick" and "thin." As we have shown, all OECD countries managed to create high learning performance education systems before ICT for accountability was an option.

Only when account-based accountability is thriving can accounting-based accountability be layered on top. Given a dysfunctional system, accounting-based can be part of a bundle that does produce significant gains-but only a part. This is also much more likely to be the case when adoption is determined by, and driven by, local school systems. As every parent or teacher knows, the same individual may reject or adopt an input based more on whether their adoption is voluntary than on the technical effects of the input. The prospects of accounting-based accountability in general and Accountability ICT specifically as a class of "treatment" to be "administered" in education to "target populations" are, in our view, exceedingly dim.

The danger is that the promise of accounting-based accountability leads people to focus on solutions to governance, accountability, and management problems of the type that the hotly marketed EMIS systems sell at the expense of, and perhaps to the detriment of, horizontal accountability-like the creation and internalization of strong professional norms among teachers, and making account to their students, parents, and communities. Improving account-based accountability often requires a verb like "nurtured" or "cultivated" rather 
than those we might more readily associate with Accountability ICT, or accounting-based accountability more generally—e.g. "rolled out".

If teachers' or student's physical presence in class were sufficient to yield step-changes in education systems, then we might expect accounting-based accountability to be a great solution. We don't think this is the case; by which we do not mean to say, for example, that teachers showing up to class isn't a necessary part of improving education systems. But if we recognize that accounting-based accountability isn't sufficient, then we can instead focus on where, when, and how accounting-based accountability can be an input into a broader account-based accountability process. And that means putting situation analysis and governance questions front and center, rather than focusing on the prospects of accountingbased accountability tools of observation as the main catalyst of change.

To return to the cameras with which this paper began, the Seva Mandir success in NGO-run schools was, to reiterate, learning gains of .17 of a standard deviation, or the equivalent of a move from the $50^{\text {th }}$ to about the $57^{\text {th }}$ percentile. This is a real gain, but it is very, very far from a transformational one. Around the same time that Duflo et. al. (2012) were surveying the 7-10 year old students who produced these gains, the Indian national ASER survey found that more than $25 \%$ of Indian grade 4 students (the same age as US $3^{\text {rd }}$ graders) could not read a single word and only $30 \%$ achieved the highest level of performance-being able to read a story written at a grade 2 level (the same age as US $1^{\text {st }}$ graders). ${ }^{24}$ What does a shift of 7 percentile points mean in such a context - that, if applied nationwide and with fidelity to the original design, as many as $40 \%$ of Indian students will achieve the high bar of being only two reading levels behind? That less than $20 \%$ of Indian grade 4 students might be unable to read a single word? 25

We are being slightly unfair. In a country of over a billion people, small gains in learningeven those smaller than in the original Duflo et al. (2012) study-would improve the education, and ultimately the welfare, of very large numbers of people. Additionally, it is possible — even likely — that the magnitude of the gains could compound over time were teachers increasingly present for the entirety of the student's lifetime. But set against these potential gains at the experiment's extensive margin are the difficulties of increasing the intensive margin. A given teacher cannot be present in the same classroom twice. Once absenteeism falls to 0 , there is nowhere else to go.

Teacher attendance is, to reiterate, a necessary part of delivering better education. Cameras may be able to improve teacher attendance at scale, and produce real learning gains as a result. But we think there is something worse than an attempt to implement cameras being

\footnotetext{
24 The Duflo et al. endline survey was in late 2007; ASER data is from the 2008 ASER study. ASER results as summarized in Pritchett 2013, page 29.

25 As alluded to in the introduction, there is also very good reason to believe that it will be difficult to realize even these gains; that school systems will resist formal adoption of cameras in classrooms, or that if adopted they will be thwarted in implementation. Experience tells us that transparency and accountability interventions are less likely to work where they face "obstacles of collective action, political resistance, and long implementation chains" (Kosack and Fung, 2014 p. 65)
} 
thwarted by politics: that attempt succeeding. If absenteeism falls to 0 as the result of thin accounting-based accountability, it will achieve this only by shifting teachers towards a "Theory X" equilibrium (see Table 1) of demotivated teachers. The result will be an education system where increasingly, to crib from James Scott (1990), any ground left unobserved from above is likely to be ground lost. ${ }^{26}$ This will be an education system where the only things accountability prompts teachers to do are things that can be observed and verified - which, unfortunately, are far from coterminus with the set of things needed to deliver quality education.

Our view is that even where accounting-based accountability solutions show results, they do so by advancing progress on a dead-end road, one which terminates far below the desired summit of transformed systems. Once at that dead end, we predict, there will be no further way "up"; one cannot build on accounting-based accountability's real but modest successes to reach the summit. Instead, one will arrive at the dead end with a vehicle less capable of reaching the summit than was present at the outset, as the car has deteriorated along the journey. Even if cameras are the most straightforward way to achieve teacher attendance, they are the wrong one. We need instead to think about how to improve "thick" accountability to students and parents in a way that not only addresses teacher attendance but also addresses what happens when teaches do show up. Students need Theory Y education systems with motivated and engaged teachers, and accounting-based accountability solutions move us away rather than towards that Theory Y world. Theory X systems steeped in accounting-based accountability will sometimes be better than the status quo, but won't be able to deliver the education all children deserve.

We have used words like "often" and "usually" and "frequently" throughout this paper when describing the flaws of accounting-based accountability because there are important things, like delivering the mail via the post office, for which primarily accounting-based accountability does indeed work well. In addition, there is a very large class of organizations-including armies in Table 3, but also education and health systems-for which accounting can be, under the right conditions, a useful (though not primary) component of an account. But for this large class of organizations accounting-based accountability is not the thin edge of the spear- the foot in the door that will lead to transformation - but rather an extra layer of armor, something that will enhance performance only if appropriately tailored and introduced as a component of, not a substitute for, account-based accountability. "Real" accountability which will drive systems transformation in education and far beyond often is thick, account-based accountability. For all our sakes, and global welfare, we believe it is time to reclaim what the term "accountability" in fact can, and should, mean.

\footnotetext{
26 The original quote is "any ground left undefended is likely to be ground lost" (Scott 1990, page 195), and is a vivid way of illustrating what contract theory would call the multitask problem - where agents focus only on what can be observed (Holmstrom Milgrom 1991) - in the extreme.
} 


\section{References}

“Account.” Merriam-Webster. Accessed February 10, 2019. https://www.merriamwebster.com/dictionary/account

“Accountable." Merriam-Webster. Accessed February 10, 2019. https://www.merriamwebster.com/dictionary/accountable.

“Accountability." Merriam-Webster. Accessed February 10, 2019. https://www.merriamwebster.com/dictionary/accountability.

Aghion, Phippe, Jean Tirole. "Formal and Real Authority in Organizations. Journal of Political Economy, 105(1). 1997.

Aiyar, Yamini, Shrayana Bhattacharya. "The Post Office Paradox: A Case Study of the Block Level Education Bureaucracy.” Economic and Political Weekly, 11. 2016.

Altinok, Nadir, Noam Angrist, Harry Anthony Patrinos. "Global data set on education quality (1965-2015.” World Bank Policy Research Worker Paper. January 23, 2018. Accessed February 13, 2019. http://documents.worldbank.org/curated/en/706141516721172989/Global-data-seton-education-quality-1965-2015

Andrews, Matt, Lant Pritchett and Michael Woolcock. Building State Capability: Evidence, Analysis, Action. Oxford, UK: Oxford University Press, 2017.

ASER. Trends over time: 2006-2014 - a supplement to ASER 2014. New Delhi: ASER, 2015.

“Assessment." Teaching at the Right Level. Accessed February 10, 2019. https://www.teachingattherightlevel.org/the-tarl-approach/assessment/.

Baker, George, Robert Gibbons, and Kevin J. Murphy. "Subjective Performance Measures in Optimal Incentive Contracts." The Quarterly Journal of Economics 109:4, 1125-1156. 1994.

. "Informal Authority in Organizations." Journal of Law, Economics, and Organization 15:1, 56-73. 1999.

. "Relational Contracts and the Theory of the Firm." The Quarterly Journal of Economics 117:1, 39-84. 2002.

Banerjee, Abhijit, Rukmini Banerji, James Berry, Esther Duflo, Harini Kannan, Shobhini Mukherji, Marc Shotland, and Michael Walton. "Mainstreaming an effective intervention: Evidence from randomized evaluations of "Teaching at the Right Level" in India." No. w22746. National Bureau of Economic Research, 2016.

Banerjee, Abhijit V., Esther Duflo, and Rachel Glennerster. "Putting a Band-Aid on a Corpse: Incentives for Nurses in the Indian Public Health Care System." Journal of the European Economic Association 6, no. 2-3 (2008): 487-500. doi:10.1162/jeea.2008.6.2-3.487.

Beatty, Amanda, Emilie Berkhout, Luhur Bima, Thomas Coen, Menno Pradhan and Daniel Suryadarma. "Indonesia Got Schooled: 15 Years of Rising Enrollment and Flat Learning Profiles." RISE Working Paper 18/026. 2018.

Belle, Nicola and Edoardo Ongaro. "NPM, Administrative Reforms and Public Serivce Motivation: Improving the Dialogue Between Research Agendas." International Review of Administrative Sciences 80:2, pgs 382-400. 
Bold, T., Filmer, D., Martin, G., Molina, E., Rockmore, C., Stacy, B., ... \& Wane, W. (2017). What Do Teachers Know and Do? Does It Matter?. Policy Research Working Paper 7956, World Bank.

Bold, T., M. Kimenyi, G. Mwabu, A. Ng'ang'a, J. Sandefur. "Experimental Evidence on Scaling Up Education Reforms in Kenya." (2018) Journal of Public Economics 168, 1-20.

Bower, Joseph L and Clayton Christensen. "Disruptive Technologies: Catching the Wave." Harvard Business Review. 2013.

Bowles, Samuel and Sandra Polania-Reyes. "Economic Incentives and Social Preferences: Substitutes or Complements?" Journal of Economic Literature 50:2, 368-425. 2012.

Brafman, Ori and Rod A. Beckstrom. The Starfish and the Spider: The Unstoppable Power of Leaderless Organizations. S.I: Penguin Putnam, 2008.

Bragg, Billy. "Not Everything That Counts" Bridges Not W alls. Cooking Vinyl Records, 2017.

Chandler, Alfred D. The Visible Hand: The Managerial Revolution in American Business and Scale and Scope. Library of Congress Cataloging. 1977.

Cristia, Julián P., Pablo Ibarrarán, Santiago Cueto, Ana Santiago, and Eugenio Severín. "Technology and Child Development: Evidence from the One Laptop per Child Program.” Inter-American Development Bank Working Paper 304. 2012.

Dewatripont, Mathias, Ian Jewitt, and Jean Tirole. The Economics of Career Concerns, Part II: Application to Missions and Accountability of Government Agencies. Review of Economic Studies 66:1, 199-217.

Dhaliwal, Iqbal and Rema, Hanna. "Deal with the Devil: The Successes and Limitations of Bureaucratic Reform in India." National Bureau of Economic Research: NBER Working Paper No. 20482. 2014.

Dixit, Avinash "Incetnives and Organizations in the Public Sector: An Interpretative Review. The Journal of Human Resources 37:4, 696-727. 2002.

Dubnick, Mel and Ciaran O'Kelly. "Accountability Through Thick and Thin: Moral Agency in Public Service", in Ethics in Public Management, eds. H George Frederickson and Richard K. Ghere, New York: M.E. Sharpe, 2005.

Duflo, Esther, Rema Hanna, and Stephen P. Ryan. "Incentives Work: Getting Teachers to Come to School." American Economic Review 102(4), 1241-1278. 2012.

Feenstra, Robert C., Robert Inklaar and Marcel P. Timmer. "The Next Generation of the Penn World Table” American Economic Review, 105 no. 10 (2015). 3150-3182, available for download at www.ggdc.net/pwt

Fox, Jonathan. "The uncertain relationship between transparency and accountability." Development in Practice, 17:4-5, 663-671. 2007.

Fullan, M. and K. Donnelly. Alive in the Swamp: Assessing Digital Innovations in Education. NESTA: London, UK, 2013.

Geertz, Clifford. The Interpretation of Cultures. HarperCollins Publishers, 1973.

Gibbons, Robert and Robert S. Kaplan. Formal Measures in Informal Management: Can a Balanced Scorecard Change a Culture? American Economic Review: Papers \& Proceedings 105 (5), 447-451. 2015.

“Global Data Dashboard Aims to Tackle Education Crisis." Safety \& Security Manager | Devex. January 22, 2019. Accessed February 10, 2019. https://www.devex.com/news/global-data-dashboard-aims-to-tackle-education-crisis$\underline{94172}$. 
“Global Education Policy Dashboard.” World Bank. Accessed February 10, 2019. https://www.worldbank.org/en/topic/education/brief/global-education-policydashboard.

"Global Student Information System Market to Grow at 16\% CAGR Through 2022 | Technavio." Accessed February 10, 2019. https://www.businesswire.com/news/home/20180518005669/en/Global-StudentInformation-System-Market-Grow-16.

Gneezy, Uri, Stephan Meier, and Pedro Rey-Biel. “When and Why Incentives (Don't) Work to Modify Behavior.” Journal of Economic Perspectives 25:4, 191-210.

Gordon, Robert J. The Rise and Fall of American Growth: The U.S. Standard of Living since the Civil War. Princeton: Princeton University Press, 2017.

Grant, Ruth W. and Robert O. Keohane. "Accountability and Abuses of Power in World Politics.” American Political Science Review 99:1, 2005.

Gundlach, Erich, Ludger Woessmann, and Jens Gmelin. "The Decline of Schooling Productivity in OECD Countries.” The Economic Journal 111, no. 471 (2001).

Hirschman, Albert. 1967. Development Projects Observed. Washington, DC: Brookings Institution.

Holmstrom, Bengt and Paul Milgrom. "Multitask Principal-Agent Analyses: Incentive Contracts, Asset Ownership, and Job Design. Journal of Law, Economics, and Organization 7 (1991). 24-52.

Holmstrom, Bengt. "Pay for Performance and Beyond". Nobel Laureate Prize Lecture, December 8, 2016. Online at https://www.nobelprize.org/uploads/2018/06/holmstrom-lecture.pdf

Honig, Dan. Navigation by Judgment: Why and When Top down Management of Foreign Aid Doesn't Work. New York, NY: Oxford University Press, 2018.

Hull, Matthew S. Government of Paper: The Materiality of Bureaucracy in Urban Pakistan. University of California Press, 2012.

Indian Express. "Nothing Wrong With Having CCTV Cameras in Classrooms, Says Delhi High Court." September 13, 2018. https://indianexpress.com/article/india/nothingwrong-with-having-cctv-cameras-in-classrooms-says-delhi-high-court-5354830/

Kaffenberger, Michelle. "PISA-D Reveals Exceptionally Low Learning. Rise Programme. Accessed February 13, 2019. https://www.riseprogramme.org/blog/PISAD low learning

Kennedy, Robert F. Remarks at the University of Kansas, March 18, 1968. https://www.jfklibrary.org/learn/about-jfk/the-kennedy-family/robert-fkennedy/robert-f-kennedy-speeches/remarks-at-the-university-of-kansas-march-18$\underline{1968}$

Kenny, Charles. Results Not Receipts. Washington, DC: Center for Global Development, 2017. Kerr, Steven. "On the Folly of Rewarding A, While Hoping for B" Academy of Management Journal 769-783, 1975.

Kosack, Stephen and Archon Fung. "Does Transparency Improve Governance?” Annual Review of Political Science 17: 65-87. 2014.

Levy, Brian, Robert Cameron, Ursula Hoadley, Vinothan Naidoo. The Politics and Governance of Basic Education: A Tale of Two South African Provinces. Oxford: Oxford University Press. 2018. 
Mansbridge, Jane. “A Contingency Theory of Accountability.” The Oxford Handbook of Public Accountability, Bovens, Mark, Robert E. Goodin, Thomas Schillemans, eds. 2014. Doi: 10.1093/oxfordhb/9780199641253.013.0019

Mansbridge, Jane. "Rethinking Representation.” American Political Science Review 97 no. 4. 2003. 515-28.

McCubbins, Mathew D., and Thomas Schwartz. Congressional Oversight Overlooked: Police Patrols versus Fire Alarms. Emmitsburg, MD: National Emergency Training Center, 1984.

McGee, Rosie, Duncan Edwards, Colin Anderson, Hannah Hudson, Francesca Feruglio. Appropriating technology for accountability: messages from Making All Voices Count. Institute of Development Studies, 2018. https://opendocs.ids.ac.uk/opendocs/bitstream/handle/123456789/13452/RR Synth Online final.pdf

Mcgregor, Douglas. The Human Side of Enterprise. New York: Mcgraw Hill, 1960.

Moynihan, Donald P., and Sanjay K. Pandey. 2007. The Role of Organizations in Fostering Public Service Motivation. Public Administration Review 67 (1): 40-53.

Muller, Jerry. The Tyranny of Metrics. Princeton NJ: Princeton University Press, 2018.

Muralidharan, Karthik, Abhijeet Singh, Alejandro J. Ganimian. "Disrupting Education? Experimental Evidence on Technology and Instruction in India." National Bureau of Economic Research: Working Paper 22923, 2016.

Natsios, Andrew. The Clash of the Counter-bureaucracy and Development. Center for Global Development Essay, 2010. https://www.cgdev.org/sites/default/files/1424271_file_Natsios_Counterbureaucracy. pdf

Nordhaus, William D. "Two Centuries of Productivity Growth in Computing. The Journal of Economic History 67, no. 01 (2007). Doi: 10.1017/s0022050707000058.

Organization for Economic Co-operation and Development. Students, Computers and Learning: Making the Connection. PISA. Paris: OECD, 2015.

Pandey, Priyanka, Sangeeta Goyal, and Venkatesh Sundararaman. "Community Participation in Public Schools: Impact of Information Campaigns in Three Indian States.” Education Economics 17:3, 355-375, 2009.

Park, Jonghwi. "Master Plan Needed for ICT in Education.” July 5, 2017. https://www.globalpartnership.org/blog/master-plan-needed-ict-education; permalink at https://perma.cc/327T-645

Pilling, David. “Inside Liberia's Controversial Experiment to Outsource Education. Financial Times. April 21, 2017. Accessed February 13, 2019. https://www.ft.com/content/291b7fca-2487-11e7-a34a-538b4cb30025

Porter, Theodore. Trust in Numbers: The Pursuit of Objectivity in Science and Public Life. Princeton University Press, 1995.

Power, Michael. The Audit Society: Rituals of Verification. New York: Oxford University Press, 1997.

Pritchett, Lant. The Rebirth of Education: Schooling Ain't Learning. Washington DC: Center for Global Development, 2013.

. "The Risks to Education Systems from Design Mismatch and Global Isomorphism: Concepts, with Examples from India.” UNU-WIDER WP/2014/039. 2014. 
Pritchett, Lant, and Amanda Beatty. 2012. The Negative Consequences of Overambitious Curricula in Developing Countries. HKS Faculty Research Working Paper Series RWP12-035, John F. Kennedy School of Government, Harvard University.

"Release: J-PAL and Pratham Awarded Philanthropic Funding toward Education Systems Change." Teaching at the Right Level. January 18, 2019. Accessed February 10, 2019. https://www.teachingattherightlevel.org/release-j-pal-and-pratham-awardedphilanthropic-funding-toward-education-systems-change/.

Root, Rebecca. "Global Data Dashboard Aims to Tackle Education Crisis." Devex. January 22, 2019. Accessed February 13, 2019. https://www.devex.com/news/global-datadashboard-aims-to-tackle-education-crisis-94172

Ross, Terrance F. "Is It Ever Okay to Make Teachers Read Scripted Lessons?” The Atlantic. October 16, 2014. Accessed February 13, 2019.

https://www.theatlantic.com/education/archive/2014/10/is-it-okay-to-make-teachersread-scripted-lessons/381265/

Scott, James C. 1990. Domination and the Arts of Resistance: Hidden Transcripts Yale University Press.

Scott, James C. Seeing like a State How Certain Schemes to Improve the Human Condition Have Failed. New Haven, Conn.: Yale Univ. Press, 2008.

Stein, Jeremy C. "Information Production and Capital Allocation: Decentralized versus Hierarchical Firms". Journal of Finance 57:5, pgs 1891-1921. 2002.

Stimson, Henry L. 1945. Memorandum on the Effects of Atomic Bomb.

Support for ICT Master Plans is the official strategy of UNESCO's Asia-Pacific Bureau as of 2017.

http://www.unescobkk.org/fileadmin/user upload/ict/Workshops/amfie2017/UNES CO Regional Strategy - AMFIE 2017.pdf

Taylor, Frederick. Scientific Management. New York: Harper, 1917.

Tendler, Judith. 1997. Good Government in the Tropics. Johns Hopkins University Press.

Tendler, Judith, and Sara Freedheim. 1994. Trust in a rent-seeking world: Health and government transformed in Northeast Brazil. World Development 22 (12): 1771-1791.

Tillitsdelegationen (TilliT) 2018. Summary. http://tillitsdelegationen.se/wpcontent/uploads/2018/10/english-summary.pdf

"UNICEF Announces Addition of Six Start-up Companies to 2018 Investment Portfolio." UNICEF. Accessed February 10, 2019. https://www.unicef.org/press-releases/unicefannounces-addition-six-start-companies-2018-investment-portfolio.

U.S. Government. "U.S. Government Strategy on International Basic Education, FY 20192023." Accessed February 14, 2019. https://www.usaid.gov/sites/default/files/documents/1865/USG-EducationStrategy FY2019-2023 Final Web.pdf

Williamson, Oliver. Markets and Hierarchies: Analysis and Antitrust Implications. New York, NY: Free Press, 1975.

World Bank. "Education Management Information Systems: EMIS Activity Definitions." Accessed February 13, 2019. http://datatopics.worldbank.org/education/files/EducationProjects/EMISActivityDefi nitions.xlsx 
World Bank. "Education Statistics (EdStats)." Education Statistics. Accessed February 10, 2019. http://datatopics.worldbank.org/education/wDashboard/dqemis.

World Bank. "Global Education Policy Dashboard." World Bank. Accessed February 13, 2019. https://www.worldbank.org/en/topic/education/brief/global-education-policydashboard 


\section{Appendix I: "Moore's Law Amenable" and "Moore's Law Resistant" Activities}

A fundamental idea of economics is that if the net effective supply of something rises, its relative price will fall. When an input's supply rises and price falls, goods that are relatively more intensive in the use of the input will tend to have their prices fall by more than goods that are more sparing in the use of that input.

The cumulative impact of Moore's Law is a massive expansion in the supply of a very certain kind of technology. We would also expect that the costs and relative prices of goods intensive in that resource expanded through technological change to fall relative to those which are not intensive. Figure A.1 shows the evolution of prices in the USA from 1997 to 2017, measured in how many televisions one could buy for the same price. The absolute price of a (quality adjusted) television has fallen from 100 in 1997 to 3.4 in 2018. This means that if the cost of a year of college tuition could buy one television in 1997, that same cost could buy 90 televisions in 2018. Labor intensive and Moore's Law resistant services like child care similarly have increased massively in relative prices to televisions-for the cost of child care in 2018 , one could buy 70 televisions.

Note that this is not which sectors are "technology intensive" as the relative price of televisions fell massively relative to airline fares - and certainly aircraft and air travel generally are "technology intensive." An airplane is a massively more sophisticated piece of equipment and embeds a wider array of technology than a television-it is just that while some parts of aircraft like avionics are Moore's Law amenable, many of the very technological intensive elements of aircraft and air travel, like jet engines, are not.

The question is where, and when, the penetration of cheaper and more powerful processors can serve as either a) a superior substitute (in economic terms; that is, on a value $/ \$$ basis) to or b) a production/TFP-enhancing complement to prior ways of working. Processing power does not lead to meaningful complements for existing child care providers - that is, there is little production-enhancing technology to wiping soiled bottoms, or cajoling toddlers to naptime. There are also no technology-enabled superior substitutes for those working as child care providers. In avionics, computing power is a powerful complement to pilots. In the production of televisions, both the components to be assembled (the guts of the TV) and the assembly process itself are Moore's Law amenable. 
Figure A.1. Relative prices have changed massively over the last 20 years and the prices of "Moore's Law amenable" produces (e.g. televisions) have fallen by factor multiples relative to "Moore's Law resistant" activities (professional services, child care, college tuition)

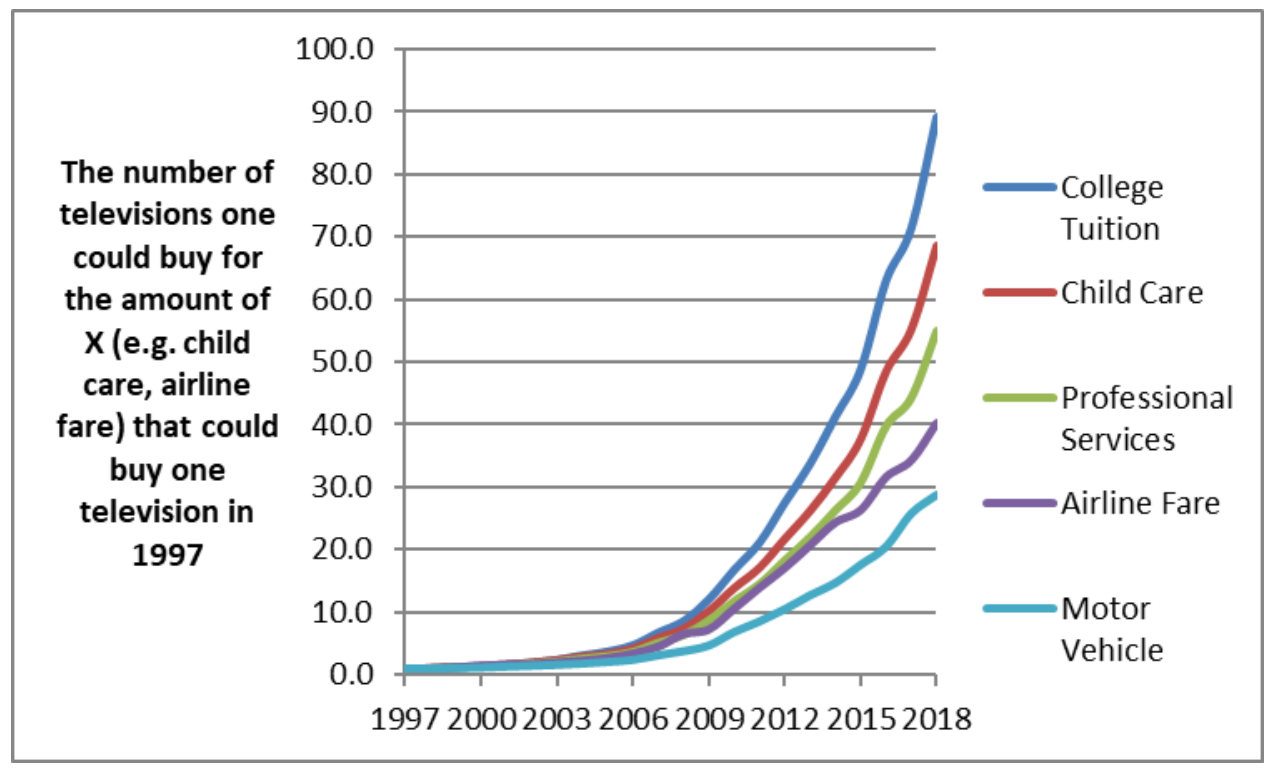

Source: Author's calculations from BLS data (https://beta.bls.gov/dataViewer /)

The simple point is that the vast expansion in one particular kind of technology changes relative productivities and hence relative prices differentially, depending on how intensively the production processes use that particular technology. So, then, if education systems were amenable to Accountability ICT, we should expect to see education systems gain in productivity (lower prices) rapidly as costs fall and penetration spreads - that is, we should expect to see education systems look more like televisions and less like college tuition in terms of either cost, or performance, or both. 


\section{Appendix II: A Modestly More Technical Approach to Evidence Suggesting That Accountability ICT in Education, and Governance More Broadly, Is Not Transformative}

One thing everyone should learn through studying statistics or econometrics is that large variation helps give precision. Using data on height and weight for US adult males, we can calculate that men who are 74 inches tall, on average weigh 189 pounds. Men who are 62 inches weigh 146. The pounds per inch arc change over the whole range is (189-146)/(74$62)=3.6$ pounds per inch. However, if one just compares weight difference across men who differ just one inch in height the pound per inch gain varies from -2 to positive 6 . So each one-inch gain is very noisy. When a phenomena of interest doesn't vary much, it is very hard to measure its impact with precision.

Suppose the expected value of any given outcome at a given time (learning, state capability, TFP growth, television prices) is related linearly (this could easily be relaxed) to a measure of ICT (computing power, price per computation) and lots of other factors (say, K of them):

$E^{\prime}\left(\right.$ Outcome $\left._{\mathrm{t}}\right)=\alpha+\beta \times J C \mathrm{~T}_{\mathrm{i}}+\sum_{i=1}^{K} \theta^{i}+Z_{\mathrm{t}}^{\mathrm{i}}$

Then the "arc change" in expected outcomes over time, given what happened with the nonICT determinants, is given by the simple difference equation:

$$
\begin{aligned}
& \beta=\frac{\left(O_{i+n}-E\left(O_{i+n} \mid Z_{i+n}\right)\right)-\left(O_{t-E} E\left(O_{t} \mid Z_{t}\right)\right)}{I C T_{i+n}-I C T_{!}^{*}}=\frac{\left(O_{i+n}-O_{!}\right)-\sum_{i=1}^{K}\left(\theta^{i} \times\left(Z_{i+n}^{i}-Z_{i}^{i}\right)\right.}{I C T_{t-i}-I C T_{i}^{i}} \\
& \beta=\frac{\Delta U_{t+\pi, i}-\sum_{i=1}^{K} \theta^{i} \Delta Z_{t-\pi, i}^{i}}{\Delta / C T_{!+\pi, i}^{i}}
\end{aligned}
$$

The simple but nevertheless worthwhile point to make is that over any extended period, say $\mathrm{N}$ of 20 or 40 or 50 , we know (from fact 1) that the change in ICT is going to be several orders of magnitude. That is, the question: "What would the world look like if there had been change in ICT capability?" isn't hypothetical in the way that "What would the world look like if the earth's orbit was three times as far from the sun?" or "What would the world look like if the USA had a female president?" is. Since 1960, measures of ICT have changed by something on the order of 8 to 11 orders of magnitude. So we know that the denominator of the ratio of the deltas is a very, very, very, big number. The thing about very big numbers in denominators is that unless the number in the numerator is similarly big, the ratio is very small.

The second point is that for a fair number of phenomena, the change in outcomes $(\Delta \mathrm{O})$ has been normatively negative (e.g. Fact 2, TFP growth is slower now than before, price of college education has risen much faster than average inflation (Fact 3), state capability has 
fallen in most developing countries (Fact 5) or $\Delta \mathrm{O}$ has been very near zero (e.g. reading ability of USA (and most OECD) teenagers). So, if we just ignore all the Zs for a second, this means $\beta$ is a negative number over a big positive number; hence, a small negative number or a very small positive number over a very big positive number. So the effect of technological change may be positive or negative - but either way the substantive effect is tiny at best.

Now take the Zs, which in the equations above represent the unobserved: everything else in the world that also has an effect on outcomes. It could be that, on net, given the patterns of changes in Zs and their likely effects, the impact of "all else" besides ICT was positive. Then this obviously makes $\beta$ even lower than if we ignored the Zs. Even for many outcomes that are stagnant, there are lots of phenomena in the developing world that most would have expected to lead to better outcomes. Many countries stopped being colonies; in the typical country GDP per capita has grown by about 2.5 fold; years of schooling has increased by about a factor of 2.5 as well; more countries are democratic; technologies besides ICT have improved; the list goes on. So, for instance, if we ask: "What would have happened to state capability in the typical developing country if ICT were unchanged?" there is no a priori or evidence-based reason to think this counterfactual, on net, would have been negative because there are some obvious changes one might have thought would lead to higher state capability (more income, higher schooling, more democracy).

There is the possibility the net change due to the Zs on outcomes is negative. If this is so, then obviously the $\beta$ ignoring the Zs underestimates the true impact of ICT. But two points.

One, you cannot use the possibility of something being so to assert that it is plausible it is so. So, perhaps learning of USA teenagers would have been worse because of the Zs. Maybe. But one would have to make specific claims about what those Zs are, and what the magnitude of the impact of those $Z s$ are $(\theta s)$, to get anything like a plausible estimate of how much different the $\beta$ would be. Since the 1970s, there has been a great deal of expansion in what people think of as positive Zs: class sizes in America have fallen, expenditures per pupil have risen substantially, and more teachers have advanced degrees. Perhaps there are offsetting negative Zs. We are not sure what they are, but possibility is not plausibility.

Two, econometricians sometimes ask themselves the question, "What would the size of the unobservables need to be for X to be true?" That is, there is a lot we can't see, and estimate, in the world - the Zs in the equations above. What would need to be true of the Zs for what we observe in section II to be hiding the real story, that "ICT is an important binding constraint that truly will improve basic education, and governance more broadly maybe, too?" Let's do that here. For phenomena that are stagnant or negative, the offsetting impact of Zs would have to be massive to make much difference-because the denominator is a phenomenally large number. Suppose that the Zs predicted that with zero change in ICT, reading scores would have deteriorated by half a standard deviation (20 points). Notably, this is massive. No country has ever seen a negative change of this magnitude. This is still 20 points divided by 2 million (six order of magnitude) so the "predicted" impact of a one order of magnitude change in ICT (which even at doubling every two years takes seven years) would be $20 / 6$ or $31 / 3$ points, less than a tenth of a standard deviation gain per seven years. 